$\mathbf{K}-25$

\section{OAK RIDGE \\ K-25 SITE}

MARTIN MARIETRA
K/EM-2,4/R1

ENVIRONMENTAL SCIENCES DIVISION

PUBLICATION NO. 4009

FEBRUARY 1993

RECEIVED

11001993

a i 


\section{DISCLAIMER}

This report was prepared as an account of work sponsored by an agency of the United States Government. Neither the United States Government nor any agency thereof, nor any of their employees, makes any warranty, express or implied, or assumes any legal liability or responsibility for the accuracy, completeness, or usefulness of any information, apparatus, product, or process disclosed, or represents that its use would not infringe privately owned rights. Reference herein to any specific commercial product, process, or service by trade name, trademark, manufacturer, or otherwise, does not necessarily constitute or imply its endorsement, recommendation, or favoring by the United States Government or any agency thereof. The views and opinions of authors expressed herein do not necessarily state or reflect those of the United States Government or any agency thereof. 
K/EM-24/R1

ENVIRONMENTAL SCIENCES DIVISION

\title{
BIOLOGICAL MONITORING AND ABATEMENT PROGRAM FOR THE OAK RIDGE K-25 SITE
}

\author{
L. A. Kszos \\ S. M. Adams \\ T. L. Ashwood \\ B. G. Blaylock \\ M. S. Greeley \\ R. L. Hinzman ${ }^{1}$ \\ J. M. Loar \\ M. J. Peterson \\ M. G. Ryon \\ B. A. Shoemaker ${ }^{2}$ \\ J. G. Smith \\ G. R. Southworth
}

${ }^{1}$ Oak Ridge Research Institute, Oak Ridge, Tennessee

${ }^{2}$ Environmental I. Ianagement Division, Oak Ridge K-25 Site

Environmental Sciences Division

Oak Ridge National Laboratory

Publication No. 4009

Manuscript Completed-January 1993

Date Published-February 1993

Prepared for

B. A. Shoemaker

Environmental Monitoring and Permitting Department

Environmental Management Division

Oak Ridge K-25 Site

Oak Ridge, Tennessee 37831

Prepared by the

OAK RIDGE NATIONAL LABORATORY

Oak Ridge, Tennessee 37831-6285

managed by

MARTIN MARIETTA ENERGY SYSTEMS, INC.

for the

U.S. DEPARTMENT OF ENERGY

under contract DE-AC05-84OR21400 


\section{CONTENTS}

Page

LIST OF FIGURES $\ldots \ldots \ldots \ldots \ldots \ldots \ldots \ldots \ldots \ldots \ldots \ldots \ldots \ldots$

LIST OF TABLES $\ldots \ldots \ldots \ldots \ldots \ldots \ldots \ldots \ldots \ldots \ldots \ldots \ldots \ldots \ldots$

ACRONYMS $\ldots \ldots \ldots \ldots \ldots \ldots \ldots \ldots \ldots \ldots \ldots \ldots \ldots \ldots \ldots \ldots \ldots$

PREFACE $\ldots \ldots \ldots \ldots \ldots \ldots \ldots \ldots \ldots \ldots \ldots \ldots \ldots \ldots \ldots \ldots \ldots \ldots \ldots$

ABSTRACT $\ldots \ldots \ldots \ldots \ldots \ldots \ldots \ldots \ldots \ldots \ldots \ldots \ldots \ldots \ldots \ldots \ldots \ldots \ldots \ldots$

1. INTRODUCTION (R. L. Hinzman and L. A. Kszos) $\ldots \ldots \ldots \ldots \ldots \ldots \ldots$

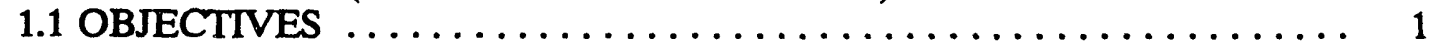

1.2 DESCRIPTION OF STUDY AREA $\ldots \ldots \ldots \ldots \ldots \ldots \ldots \ldots \ldots \ldots$

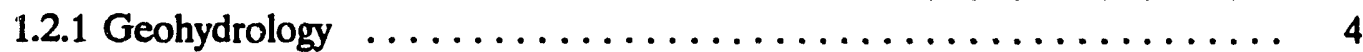

1.2.2 Description of the Oak Ridge K-25 Site Discharges $\ldots \ldots \ldots \ldots \ldots 5$

1.3 BIOLOGICAL MONITORING SITES ................ 7

2. BIOLOGICAL MONITORING TASKS $\ldots \ldots \ldots \ldots \ldots \ldots \ldots \ldots \ldots \ldots$

2.1 TOXICITY MONITORING (TASK 1) (L. A. Kszos) $\ldots \ldots \ldots \ldots \ldots \ldots 10$

2.1.1 Introduction ............................... 10

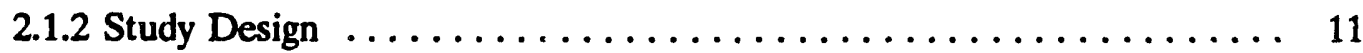

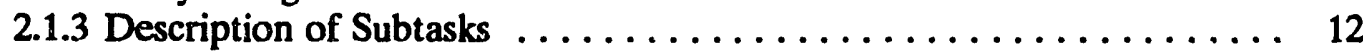

2.2 BIOACCUMULATION MONITORING (TASK 2) $\ldots \ldots \ldots \ldots \ldots \ldots$

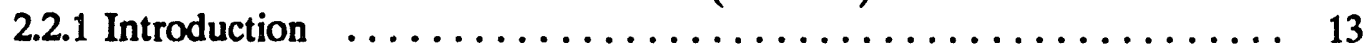

2.2.2 Contaminant Accumulation in Aquatic Biota (Subtask 2a)

(M. J. Peterson and G. R. Southworth) $\ldots \ldots \ldots \ldots \ldots \ldots \ldots$

2.2.3 Contaminant Accumulation in Terrestrial Biota (Subtask 2b)

(T. L. Ashwood and B. G. Blaylock) $\ldots \ldots \ldots \ldots \ldots \ldots \ldots \ldots \ldots \ldots$

2.3 ASSESSMENT OF FISH HEALTH (TASK 3) $\ldots \ldots \ldots \ldots \ldots \ldots \ldots . \ldots . \ldots . \ldots$

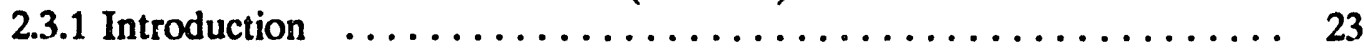

2.3.2 Bioindicators (Subtask 3a) (S. M. Adams) . . . . . . . . . . 25

2.3.3 Reproductive Effects (Subtask 3b) (M. S. Greeley) . . . . . . . 31

2.4 INSTREAM MONITORING (TASK 4) $\ldots \ldots \ldots \ldots \ldots \ldots \ldots \ldots \ldots$

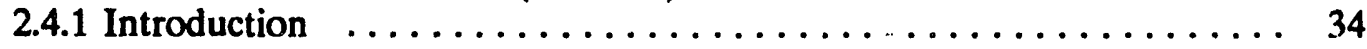

2.4.2 Benthic Macroinvertebrates (Subtask 4a) (J. G. Smith) . . . . . . 35

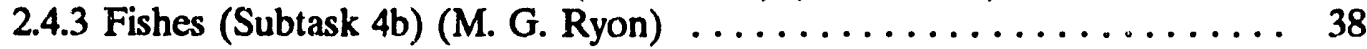

3. ABATEMENT PROGRAM (B. A. Shoemaker) $\ldots \ldots \ldots \ldots \ldots \ldots \ldots \ldots$

4. LITERATURE CITED $\ldots \ldots \ldots \ldots \ldots \ldots \ldots \ldots \ldots \ldots \ldots \ldots \ldots$ 


\section{LIST OF FIGURES}

$\begin{array}{ll}\text { Figure } & \text { Page }\end{array}$

1 Map of the Oak Ridge K-25 Site area showing the location of sampling sites

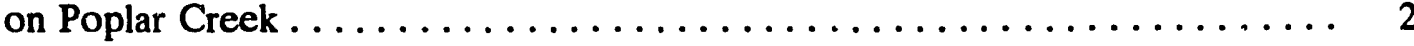

2 Map of the proposed sampling sites on Mitchell Branch $\ldots \ldots \ldots \ldots \ldots \ldots$

3 Map of the waterfowl observation stations for the K-25 Site. . . . . . . 17

4 The continuum, along gradients of response time and ecological relevance, of biological responses of fish to environmental stress . . . . . . . . . . . . 


\section{LIST OF TABLES}

Table

Page

1 Location of the biological monitoring sites nn Mitchell Branch, Poplar Creek, Clinch River, and unnamed tributaries $\ldots \ldots \ldots \ldots \ldots \ldots \ldots \ldots \ldots \ldots \ldots \ldots$

2 Fraction of toxicity tests of effluent discharged from storm drains 170,180 , and 190 showing toxicity from a source other than chlorine $\ldots \ldots \ldots \ldots \ldots \ldots$

3 Summary of the proposed monitoring plan for aquatic biota, listing the species and analytes for each of nine sampling sites $\ldots \ldots \ldots \ldots \ldots \ldots \ldots \ldots \ldots$

4 Sampling plan for the biological indicators task $\ldots \ldots \ldots \ldots \ldots \ldots \ldots$ 


\section{ACRONYMS}

BMAP Biological Monitoring and Abatement Program

CNF Central Neutralization Facility

CRK Clinch River kilometer

CRRI Clinch River Remedial Investigation

DOE U.S. Department of Energy

EFPC East Fork Poplar Creek

EMD Environmental Management Division

EPA U.S. Environmental Protection Agency

EPT Ephemeroptera, Plecoptera, and Trichoptera

EROD 7-ethoxyresorufin $O$-deethylase

FDA Food and Drug Administration

GCK Grassy Creek kilometer

GLM general linear model

IROD Interim Record of Decision

MIK Mitchell Branch kilometer

NPDES National Pollutant Discharge Elimination System

OPP Organic priority pollutants

ORNL Oak Ridge National Laboratory

ORR Oak Ridge Reservation

PAH polycyclic aromatic hydrocarbon

PCB polychlorinated biphenyl

PCK Poplar Creek kilometer

QA quality assurance

QC quality control

RCRA Resource Conservation and Recovery Act

SD storm drain

SWPP Storm Water Pollution Prevention Plan

TDEC Tennessee Department of Environment and Conservation

TRC total residual chlorine

TSCA Toxic Substances Control Act 


\section{PREFACE}

The proposed Biological Monitoring and Abatement Program (BMAP) for the Oak Ridge K-25 Site, as described in this document, will be conducted for the duration of the renewed National Pollutant Discharge Elimination System permit issued for the Oak Ridge K-25 Site on October 1, 1992. The basic approach to biological monitoring used in this program was developed by staff in the Environmental Sciences Division (ESD) at the Oak Ridge National Laboratory (ORNL) at the request of the K-25 Site. The proposed BMAP is based on results of biological monitoring conducted during the period of 1986 to 1992 and from discussions held on November 12, 1992, between staff of Martin Marietta Energy Systems, Inc. (ORNL and K-25 Site), and the Tennessee Department of Environment and Conservation (TDEC), Department of Energy Oversight Division. The technical reviews and consultation provided by Barbara Rector of TDEC and S. W. Christensen and A. J. Stewart of ESD were instrumental in the development of the proposed BMAP.

Although details of the specific procedures used in the current routine monitoring program are provided, experimental designs for future studies to be implemented after the first year are described in less detail. The overall strategy is to use the results obtained from each task to define the scope of future monitoring efforts. Such efforts may require more intensive sampling than initially proposed in some areas (e.g., additional toxicity testing if initial results indicate low survival or growth) or a reduction in sampling intensity in others (e.g., reduction in the number of sampling sites when no impact is observed). By using the results of previous monitoring efforts (J. G. Smith et al., unpublished data) to define the needs and short-term goals of future studies, an effective, integrated monitoring program can be developed to assess the impacts of K-25 Site operations on the biota of Mitchell Branch, Poplar Creek, and the Poplar Creek embayment of the Clinch River and to document the ecological effects of remedial actions. 


\begin{abstract}
A proposed Biological Monitoring and Abatement Program (BMAP) for the Oak Ridge K-25 Site was prepared in December 1992 as required by the renewed National Pollutant Discharge Elimination System permit that was issued on October 1, 1992. The proposed BMAP is based on results of biological monitoring conducted from 1986 to 1992 and discussions held on November 12, 1992, between staff of Martin Marietta Energy Systems, Inc. (Oak Ridge National Laboratory and the K-25 Site), and the Tennessee Department of Environment and Conservation, Department of Energy Oversight Division.

The proposed BMAP consists of four tasks that reflect different but complementary approaches to evaluating the effects of K-25 Site effluents on the ecological integrity of Mitchell Branch, Poplar Creek, and the Poplar Creek embayment of the Clinch River. These tasks include (1) ambient toxicity monitoring, (2) bioaccumulation monitoring, (3) assessment of fish health, and (4) instream monitoring of biological communities. This overall BMAP plan combines established protocols with current biological monitoring techniques to assess environmental compliance and quantify ecological recovery. The BMAP will also determine whether the effluent limits established for the K-25 Site protect the designated use of the receiving streams (Mitchell Branch, Poplar Creek, and Clinch River) for growth and propagation of fish and other aquatic life. Results obtained from this biological monitoring program will also be used to document the ecological effects (and effectiveness) of remedial actions.
\end{abstract}




\section{INTRODUCTION}

On October 1, 1992, a renewed National Pollutant Discharge Elimination System (NPDES) permit was issued for the Oak Ridge K-25 Site (a former uranium-enrichment production facility known as the Oak Ridge Gaseous Diffusion Plant), which is managed by Martin Marietta Energy Systems, Inc., for the U.S. Department of Energy (DOE). As specified in Part III (F) of the permit, a plan is required for the biological monitoring of Mitchell Branch, Poplar Creek, Poplar Creek embayment of the Clinch River, and any unnamed tributaries to these streams deemed appropriate and shall be submitted to the Tennessee Department of Environment and Conservation (TDEC), Division of Water Pollution Control, within 90 days of the effective date of the permit. The Biological Monitoring and Abatement Program (BMAP), as outlined in Sect. 2, was developed to address this requirement.

\subsection{OBJECTVES}

The initial RMAP (Loar et al. 1992a) was developed to meet two major objectives. First, studies were designed to provide sufficient data to determine whether the effluent limitations establitised for the K-25 Site protect and maintain the use of Mitchell Branch for growth and propagation of fish and other aquatic life. The second major objective was to document the resulting effects $r \cdot 2$ stream biota of operation of major new pollutionabatement facilities, which include the Central Neutralization Facility (CNF) and the Toxic Substances Control Act (TSCA) incinerator. Unlike the first objective, wherein biological monitoring was used to determine compliance, this objective employed biological criteria to evaluate the effects of specific pollution-control measures.

The initial BMAP has been modified based on results of the biological monitoring conducted since 1986 and discussions with TDEC on November 12, 1992. The objectives of the proposed BMAP place more emphasis on temporal than spatial trends, while continuing to investigate/identify contaminant sources associated with observed adverse effects. Previous biological monitoring provided a detailed spatial characterization of ecological impacts at numerous sites on Mitchell Branch. The new BMAP puts more emphasis on monitoring stream recovery through time in order to assess the effects (and effectiveness) of remedial actions.

\subsection{DESCRIPTION OF STUDY AREA}

Mitchell Branch is a small stream located near the northeast boundary of the Oak Ridge K-25 Site (Figs. 1 and 2). The stream has a drainage area of $1.78 \mathrm{~km}^{2}$ and is similar in size to upper Grassy Creek [ $2.59 \mathrm{~km}^{2}$ at Grassy Creek kilometer (GCK) 2.4], a reference stream located about $2 \mathrm{~km}$ southeast of the K-25 Site. Mitchell Branch flows $\sim 1.5 \mathrm{~km}$ from its headwaters to its mouth at Poplar Creek, which is $\sim 150 \mathrm{~m}$ downstream of the Blair Road bridge (Fig. 2). The confluence of the two streams is $\sim 1.5 \mathrm{~km}$ below the mouth of East Fork Poplar Creek (EFPC) and $-7 \mathrm{~km}$ above the confluence of Poplar Creek with the Clinch River. 


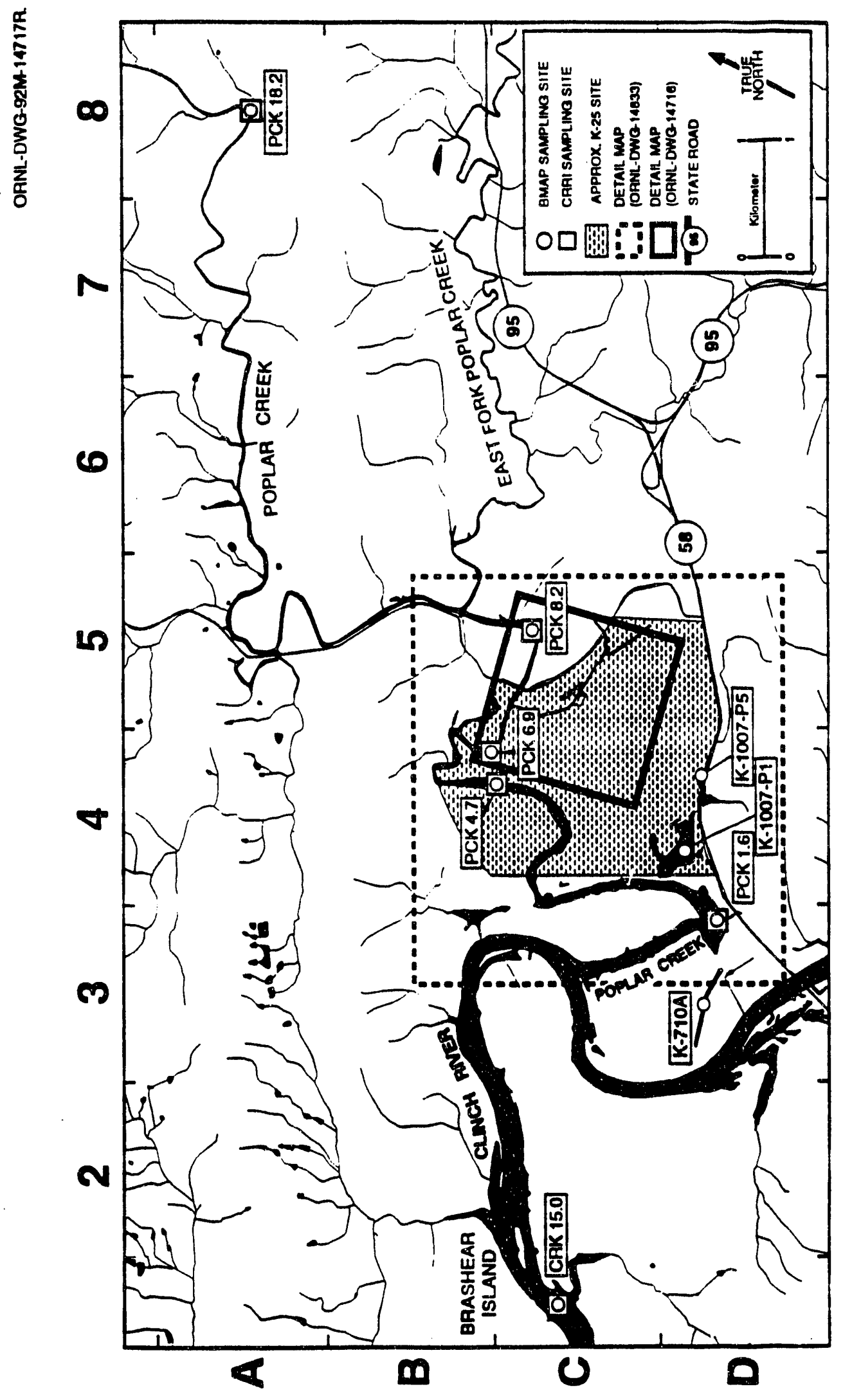

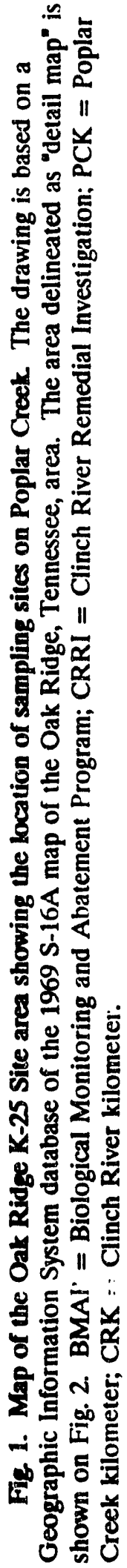




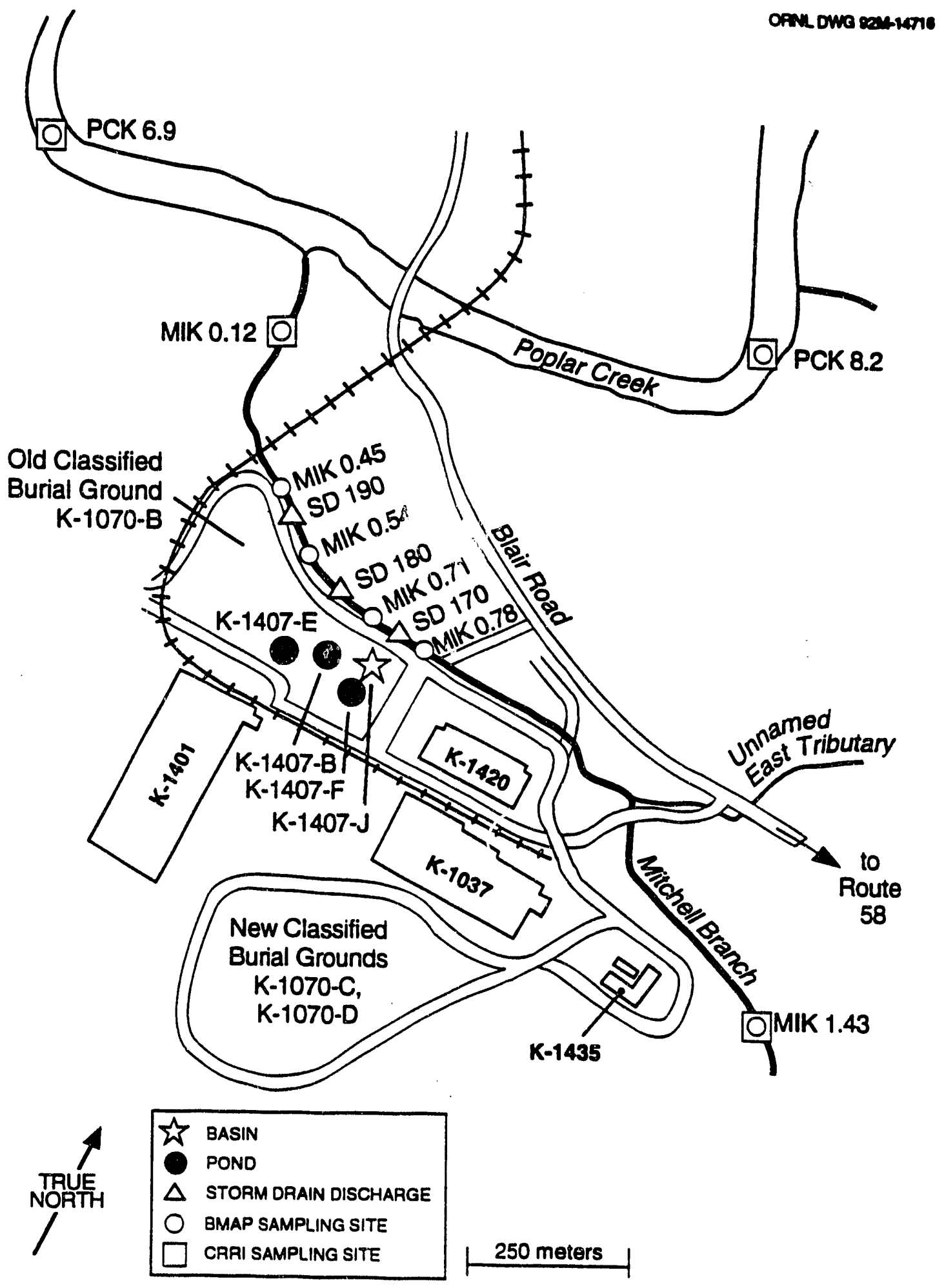

Fig. 2. Map of the proposed sampling sites on Mitchell Branch. BMAP = Biological Monitoring and Abatement Program; CRRI = Clinch River Remedial Investigation; MIK = Mitchell Branch kilometer; PCK = Poplar Creek kilometer; $S D=$ Storm drain. 
Poplar Creek has a drainage area of $352 \mathrm{~km}^{2}$; the creek originates northeast of Oliver Springs, Tennessee, on the Cumberland Plateau. Streamflow in Poplar Creek is southeasterly, entering the DOE Oak Ridge Reservation (ORR) north of the K-25 Site and flowing $\sim 10 \mathrm{~km}$ through the plant area before entering the Clinch River near Clinch River kilometer (CRK) 19.3. EFPC, a major tributary of Poplar Creek, originates from springs on the northwest slope of Chestnut Ridge within the boundaries of the Oak Ridge Y-12 Plant. Streamflow of EFPC is augmented by Y-12 Plant discharges. Flow can be controlled as it leaves the site by Lake Reality, a 1.0-ha settling pond located $\sim 1.5 \mathrm{~km}$ below the springs. The creek flows for $\sim 24 \mathrm{~km}$ before joining the West Fork at Poplar Creek kilometer (PCK) 8.8.

\subsubsection{Geohydrology}

\subsubsection{Mitchell Branch}

Mitchell Branch originates near the base of a small knoll southwest of McKinney Ridge. The knoll is underlain by the Conasauga Group, which consists of a calcareous shale interbedded with thinner layers of limestone and siltstone. Streams that are underlain by shale and sandstone, such as Mitchell Branch, have a smaller low-flow discharge and greater range in flow than streams underlain by carbonate rocks (McMaster 1967).

Periods of zero discharge sometimes occur in portions of Mitchell Branch just upstream of the BMAP sampling site (Fig. 2) at Mitchell Branch kilometer (MIK) 0.86 [J. 3 . Smith, Environmental Sciences Division, Oak Ridge National Laboratory (ORNL), personal observation]. Periods of zero discharge also occur in upper Melton Branch near ORNL (J. M. Loar, unpublished data), a small stream that is also underlain predominantly by shale and sandstone (Table 10 in McMaster 1967).

During the 1986-90 study periods, discharges from the K-25 Site augmented the flow of Mitchell Branch at ambient monitoring station K-1700 (MIK 0.12) by $-31 \%$ (oncethrough cooling water and process water accounted for $-21 \%$ and $10 \%$ respectively). Surface runoff probably accounted for most of the remaining flow (Kasten 1986), although there were minor contributions from groundwater (Table 7 in Scheib 1987) and burial ground seeps. However, in years of below-normal precipitation and minimal runoff, such as in 1985-87, nearly $100 \%$ of the flow in the stream could have been plant effluent. The potential benefit derived from increasing the minimum flow in the stream (i.e., reduction in stream bed dewatering and habitat loss) could have been offset by the adverse impacts of insufficient dilution of these effluents.

An engineering project completed in October 1992 has almost eliminated oncethrough cooling water, and a pipeline completed in September 1989 eliminated processwater discharges to Mitchell Branch; however, a minimal amount of discharge still continues from building sumps and burial ground seeps (B. A. Shoemaker, Environmental Management Division, K-25 Site, personal communication, December 1992).

Discharge in Mitchell Branch varies less than in other streams that lack flow augmentation. However, temporal variation in discharge from Mitchell Branch was 
greater than the variation in EFPC at East Fork kilometer 5.3, where flow is augmented by up to $50 \%$ in dry years. Flow augmentation may be beneficial to some biota (Lowry et al. 1987). For example, Horowitz (1978) found that more species of fish occurred in streams where flow was more constan..

\subsubsection{Poplar Creek}

Poplar Creek is the largest tributary of the Clinch River between Melton Hill Dam and the northwest boundary of ORR. Its average annual discharge is approximateiy ten times greater than the combined discharges of other tributaries in this $21-\mathrm{km}$ reach of the river (Loar et al. 1981). The creek flows from Poplar Creek Valley, which is u lain by the Conasauga shale, through a gap in Black Oak Ridge, which is underlain by t:e Knox Formation, and enters the Clinch River southeast of the K-25 Site. With the exception of the silty shale and siltstone-saristone members of the Rome Foundation adjacent to Route 58 southeast of the plant, most of the K-25 Site is underlain by Chickamauga Limestone (DOE 1979).

Poplar Creek discharge patterns generally reflect precipitation and runoff patterns typical of this region of East Tennessee. Maximum precipitation is in the winter (December-February) when approximately $31 \%$ of the annual precipitation occurs. The wettest months are February and March (NOAA 1990). Water 16 vels in Poplar Creek are also influenced by the operation of two Tennessee Valley Authority (TVA) dams: Melton Hill Dam at CRK 37.2 (completed in 1963) and Watts Bar Dam located at Tennessee River kilometer 852 (completed in 1942). Dam operations affect not only the magnitude and frequency of water-level fluctuations, but they also influence water velocities and direction of flow in the lower reaches of Poplar Creek.

\subsection{Description of the Oak Ridge K-25 Site Discharges}

\subsubsection{Mitchell Branch}

Historically, noint-source discharges to Mitchell Branch from K-25 Site operations fell into one of two inain categories: process water or storm drain effluents. Before October 1988, wastes from the uranium recovery facility, the metals cleaning facility, the chemical process development facility, the steam plant, and the coal yard were neutralized in a $1.1 \times 10^{5}-\mathrm{L}$ vat prior to discharge into the K-1407-B pond. Metal hydroxides were allowed to settle to the bottom of the pond, and the supernatant was conveyed via a ditch to Mitchell Branch.

Closure of the K-1407-B pond began on October 31, 1988, under the Resource Conservation and Recovery Act (RCRA). The pond now receives only rainwater and surface runoff, which are pumped to the CNF for treatment before being discharged to Poplar Creek. On November 1, 1988, the K-1407-B pond was replaced with the K-1407-E and K-1407-F ponds and the K-1407-J settling basin (Fig. 2).

In February 1991, effluents from the K-1407-E/F ponds [two holding ponds constructed primarily for settling solids and $\mathrm{pH}$ control (K-1407-E, volume $\approx 781,000 \mathrm{~L}$; $\mathrm{K}-1407-\mathrm{F}$, volume $\approx 1,320,000 \mathrm{~L}$ )] were rerouted to CNF for treatment. Effluents from 
CNF are discharged into the K-1407-J settling basins. A pipeline to Poplar Creek at K801 was put into service on September 1, 1989, to convey effluents from the K-1407-J settling basins. Effluents from K-1407-E/F and K-1407-J were previously discharged to Mitchell $\mathrm{Br}$ inch. Process water is no longer routinely discharged to Mitchell Branch. In the event ing precipitation, overflow from the K-1407-E/F ponds may be discharged to Mitcheli zranch through storm drain (SD) 170 and SD 180; however, this operation will cease by October 1994 in accordance with a compliance schedule in the revised NPDES permit. Prior to August 1987, some coal yard runoff and boiler blowdown were discharged directly to the stream through SD 170 just upstream of the K-1407-B pond outfall. Following the construction of CNF in 1986, coal pile runoff and steam plant effluents were rerouted for treatment at CNF and discharged through the $\mathrm{K}-1407-\mathrm{E} / \mathrm{F}$ ponds. Following the conversio of the steam plant boiler from coal to natural gas, the coal pile was removed in the summer of 1992 , and remediation of the site is nearing completion.

Treated effluent from CNF is pumped to the K-1407-J settling basin. CNF has two treatment modes, "hazardous" and "nonhazardous." Included in the "hazardous" treatment mode are effluents from the TSCA incinerator; nonhazardous treatment includes coal pile runoff and steam plant effluents. After treatment, waste is pumped into the K-1407-J settling basins, transferred to the K-801 area via pipeline where it is augmented with Clinch River water, and then passed through a series of baffles before being discharged into Poplar Creek (see following Section on Poplar Creek).

Many storm drains enter Mitchell Branch. Although some of these drains contribute only runoff water and suspended particulate matter to the stream during rainfall events, others may discharge groundwater, once-through cooling water, or floor drain wastewater in addition to runoff from roofs and parking lots. Site-wide efforts are currently under way to identify and eliminate all cooling water and building drain discharges to Mitchell Branch. In the new NPDES permit, storm drains are classified according to their source and potential for contamination. Storm drains at the K-25 Site are classified as Category IV outfalls because of the potential for burial ground discharges (SD 170, SD 180, or SD 190) or discharges of chlorinated cooling water (SD 100, SD 124, or SD 130). Six storm drains are classified as Category IV outfalls (those outfalls that pose the risk of conveying pollutants that could be released to waters of the state). Of these six, three discharge to Mitchell Branch through SD 170, SD 180, or SD 190. The remaining Category IV outfalls discharge to Poplar Creek through the K-1007 ponds. There are 34 Category III outfalls that enter Mitchell Branch or Poplar Creek and 30 Category II and 69 Category I outfalls that enter Mitchell Branch, Poplar Creek, or Watts Bar Reservoir.

Leachate from waste disposal sites (i.e., area-source discharges) may also enter the stream. The old classified burial ground (K-1070-B), a 1.50-ha site located about $120 \mathrm{~m}$ west of the K-1407-B pond, was created by filling in a large swampy area that drained into Mitchell Branch. This disposal site contains both radioactive and nonradioactive wastes. An ephemeral stream drains the site, which is located within the Mitchell Branch watershed. The K-1407-C retention basin has an area of 0.80 ha and is located $120 \mathrm{~m}$ northeast of the K-1407-B pond. It was constructed in 1973 and received dredged material from other holding ponds, including K-1407-B. Although the K-1407-C basin has no surface effluent, a groundwater plume extending from the pond toward the stream has 
been detected (Ashwood et al. 1986). Both the K-1407-B pond and the K-1407-C pond are scheduled for closure under RCRA. Leachate from the classified burial ground (K-1070-C and K-1070-D) behind Building K-1037 drains to Mitchell Branch through SD 170 and SD 180. Efforts to collect and treat leachate from these areas are anticipated to begin ir 1993 (B. A. Shoemaker, Health, Safety and Environment, the K-25 Site, personal communication, December 1992).

\subsection{Poplar Creek}

Poplar Creek receives discharges from storm drains (see preceding Section on Mitchell Branch), from CNF, and from the K-1203 Sewage Treatment Plant (Outfall 005). CNF treats effluents from a variety of processes including, but not limited to (1) Building 1420 , a decontamination and recovery facility; (2) Building 1401, a metals preparation facility and machine shop; and (3) the TSCA incinerator, Building K-1435. The TSCA incinerator is used to destroy polychlorinated biphenyls (PCBs) and other hazardous wastes. Liquid discharges from the incinerator include (1) incinerator scrubber blowdown and (2) fire water (water that has been used to fight fires) and rainwater from a corlection sump. These two vaste streams are collected in a surge tank; analyzed for selected constituents; and, as appropriate, discharged to CNF, pumped through carbon-bed absorbers, or pumped to the waste feed tanks for burning in the incinerator. Other facility wastes that meet the acceptance criteria are processed through CNF, including coal pile runoff, blowdown from several processes, ion-exchange backwash, and remedial action streams.

Wastes from CNF are pumped to the $\mathrm{K}-1407-\mathrm{J}$ settling basins, two aboveground settling ponds (volume $\approx 378,000 \mathrm{~L}$ each) with an average monthly discharge that is slightly $<5 \times 10^{5} \mathrm{~L}$. Effluent from the K-1407-J settling basins is discharged in a batch mode. It is first piped to the 801 area; then augmented with water from the Clinch River which flows over a series of baffles; and finally discharged to Poplar Creek (PCK 5.1). Efforts are under way to initiate a project to extend the existing pipeline from Poplar Creek to the Clinch River (CRK 18.5) by April 1996, as required by the renewed NPDES permit.

\subsection{BIOLOGICAL MONITORING SITES}

During the initial BMAP (Loar et al. 1992b), eight sites on Mitchell Branch were sampled routinely to assess ecological conditions in the stream. Although the upper reach (MIK 1.43) was the primary reference site, other streams in the area were also used as reference sites. The lowermost site at MIK 0.12 coincided with the location of the NPDES monitoring station (K-1700). A sampling site for the bioaccumulation task was located at PCK 6.9, downstream of the mouth of Mitchell Branch. Four of the remaining six sites (MIK 0.78, MIK 0.71, MIK 0.54, and MIK 0.45) were selected based on the location of the three most significant discharges to Mitchell Branch: SD 170, SD 180 (and effluent from the K-1407-E/F holding ponds), and SD 190; these monitoring sites were located above and below each of these outfalls respectively. The remaining two sites (MIK 0.86 and MIK 1.10) were selected to assess the potential for adverse impacts 
associated with (1) construction of a storage yard located immediately northeast of Mitchell Branch and (2) minor inputs from several storm drains located further upstream.

Sampling locations for this BMAP are shown in Figs. 1 and 2 and are discussed in Table 1 and in the description of each task. Many of the tasks will share Poplar Creek and Clinch River sites with the Clinch River Remedial Investigation (CRRI). Task 1 (Toxicity Monitoring) maintains six sites in Mitchell Branch and adds new sites in Poplar Creek and the Clinch River. Task 2a (Contaminant Accumulation in Aquatic Biota) will maintain five sites (one each in Mitchell Branch and Clinch River and three in Poplar Creek) and add three new ones: Poplar Creek (one site) and two on unnamed tributaries. Task $2 \mathrm{~b}$ (Contaminant Accumulation in Terrestrial Biota) will consist of sitewide monitoring, including sites both within and adjacent to the K-25 Site. Task 3a (Assessment of Fish Health) will maintain a site in Mitchell Branch and add sites in Poplar Creek, Clinch River, and an unnamed tributary. Task 3b (Reproductive Effects) is a new subtask and will include sites in Mitchell Branch, Poplar Creek, and the Clinch River. Task 4a (Instream Monitoring of Benthic Invertebrates) will maintain four sites in Mitchell Branch and add two unnamed tributaries. Task $4 \mathrm{~b}$ (Instream Monitoring of Fish) will maintain two sites in Mitchell Branch. 
9

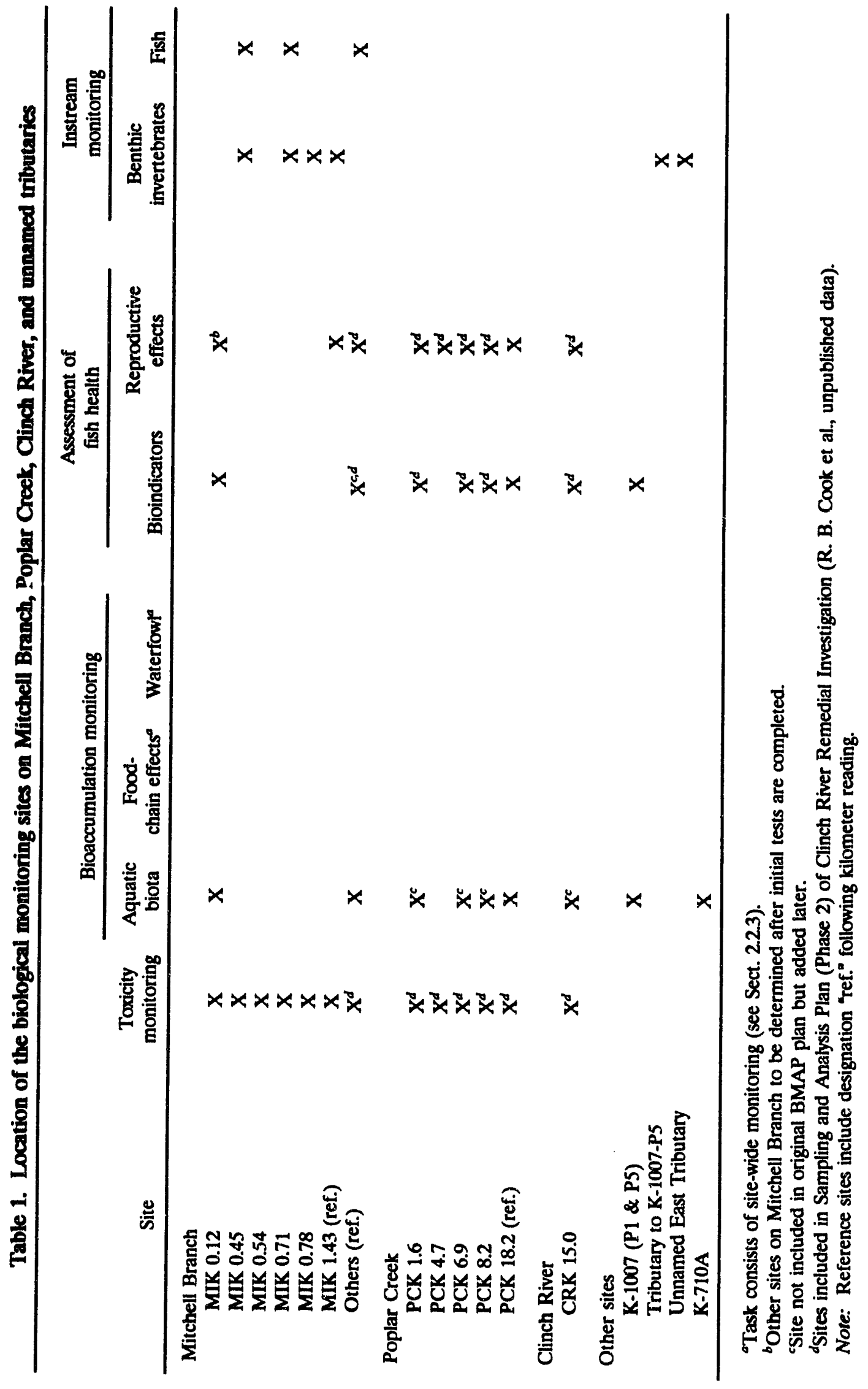




\section{BIOLOGICAL MONITORING TASKS}

The point and nonpoint discharges to Mitchell Branch and Poplar Creek are complex, consisting of trace elements, organic chemicals, and radionuclides in addition to various conventional pollutants. Moreover, the composition of these discharges will change as various remedial actions are implemented. Although contaminant inputs to Mitchell Branch and Poplar Creek originate primarily as point and nonpoint (storm drains) sources from existing plant operations, area sources, such as the K-1070-B, K-1070-C, and K-1070-D burial grounds (Sect. 1.2), are potential sources of contaminants.

Such environmental complexities require a multitiered, integrated approach to biological monitoring. Consequently, BMAP for Mitchell Branch consists of four major tasks: Toxicity Monitoring (Sect. 2.1), Bioaccumulation Monitoring (Sect. 2.2), Assessment of Fish Health (Sect. 2.3), and Instream Monitoring of Biological Communities (Sect. 2.4). These tasks combine well-established monitoring methods with more innovative and newly developed techniques to evaluate regulatory compliance.

\subsection{TOXICITY MONITORING (TASK 1)}

\subsubsection{Introduction}

Toxicity testing of effluents and ambient waters has become an integral part of the biological monitoring programs at all three facilities on the DOE ORR and at the Paducah Gaseous Diffusion Plant in Paducah, Kentucky. Ambient and effluent toxicity monitoring has been conducted at the K-25 Site since October 1986.

From 1986 to 1990 , effluents from the K-1407-B pond, K-1407-E/F ponds, and $\mathrm{K}-1407-\mathrm{J}$ settling basin were evaluated for toxicity. Effluents from the K-1407-B pond and $\mathrm{K}-1407-\mathrm{E} / \mathrm{F}$ ponds are no longer tested because of the closure of the $\mathrm{K}-1407-\mathrm{B}$ pond and rerouting of the K-1407-E/F ponds (see Sect. 1.2.2). Under the renewed NPDES permit, the K-1407-J basin (NPDES Outfall 011) and the K-1203 Sewage Treatment Plant (NPDES Outfall 005) will be evaluated for toxicity. From 1988 to June 1990, water from the K-1407-J basin was tested for toxicity at bimonthly intervals. Effluent from the K-1407-J basin was generally not toxic to fathead minnows. Ceriodaphnia, on the other hand, were much more sensitive to this effluent, with a no-observed-effect concentration (the concentration that causes no reduction in Ceriodaphnia survival or reproduction) ranging from $1 \%$ to $100 \%$. Under the previous NPDES permit, no tests were conducted for K-1203 Sewage Treatment Plant.

The ambient (instream) toxicity at six sites in Mitchell Branch was evaluated bimonthly from 1986 to 1990 . Water from the two most upstream sites in Mitchell Branch (MIK 1.43 and MIK 1.10) adversely affected fathead minnows but not Ceriodaphnia. A bacterial or fungal fish pathogen may have been involved because there were no obvious sources of toxicants at either of these sites. Water from MIK 0.71 downstream to MIK 0.45 showed strong evidence of acute toxicity to both species through 1988. In 1989 and 1990 , the incidence of acute toxicity at these sites declined. Water from MIK 0.12 
was never acutely toxic to fathead minnows, but it was acutely toxic to Ceriodaphnia in many tests conducted from 1987 through 1989. Chronic toxicity to fathead minnows was evident only in water from MIK 0.54; while chronic toxicity to Ceriodaphnia was found in water from MIK 0.71, MIK 0.54, and MIK 0.12. Evidence suggested that chlorine appeared to be the primary toxicant contributing to the acute toxicity of water from some sites. Chronic toxicity may have resulted from low levels of total residual chlorine (TRC) from the storm drains, constituents released from the K-1407-E/F ponds, and/or unidentified area-source contamination.

The purpose of the toxicity monitoring task is to assess the toxicity (to aquatic organisms) of water from Mitchell Branch, Poplar Creek, and of water from various point and nonpoint source discharges. Toxicity tests also will be used to investigate/identify contaminant sources that cause or contribute to toxicity.

Two well-established toxicity tests will be used concurrently to evaluate effluent and ambient waters: the Cladoceran (Ceriodaphnia dubia) Survival and Reproduction Test (hereafter referred to as the Ceriodaphnia test) and the Fathead Minnow (Pimephales promelas) Larval Survival and Growth Test (hereafter referred to as the fathead minnow test; Weber et al. 1989). These two tests are Environmental Protection Agency (EPA)approved for use in the NPDES program to estimate (1) chronic toxicity of effluents collected at the end of the discharge pipe and tested with a standard dilution water, (2) toxicity of receiving water downstream from or within the influence of the outfall, and (3) effects of multiple discharges on the quality of the receiving water (Weber et al. 1989). The fathead minnow and Ceriodaphnia tests are 7-d, static renewal tests. Daily observations of mortality are made for both species, and daily observations of reproduction are made for $C$. dubia. The endpoints of the Ceriodaphnia test are survival and reproduction (offspring per female). The endpoints of the fathead minnow test are survival and growth (increase in weight). The toxicity tests have several advantages over chemical analyses. They are rapid, economical, and useful in determining the toxicity of test waters to instream biota. Moreover, the toxicity tests can be used to detect toxic materials that may not be typically monitored and can estimate the toxicity of complex mixtures.

\subsection{Study Design}

The toxicity monitoring task consists of three subtasks: (1a) effluent toxicity tests, (1b) ambient toxicity tests, and (1c) storm drain survey. Subtask 1a will utilize the fathead minnow and Ceriodaphnia tests as described by Weber et al. (1989). Subtask 1b will generally follow the EPA procedures, with minor modification (e.g., no dilutions). In both subtasks, the two tests will be conducted concurrently. Subtask 1c will utilize either the 7-d chronic (Weber et al. 1989) or the 48-h acute toxicity test with Ceriodaphnia (Weber 1991 ) and the Microtox system. Microtox is a rapid, economical test using the phosphorescent marine bacterium, Photobacterium phosphoreum. Toxicity to the bacteria is quantified based on light output. The Microtox test will be conducted according to manufacturer instructions. 


\subsection{Description of Subtasks}

\subsubsection{Effluent toxicity monitoring (Subtask 1a)}

Subtask 1a will monitor the toxicity of Outfall 005 (K-1203 Sewage Treatment Plant) and Outfall 011 (K-1407-J settling basin), as specified in Part III (C) of the NPDES permit. Toxicity tests with Ceriodaphnia and fathead minnows will be conducted once every two months for a period of one year and once every six months thereafter for the duration of the permit, if no toxicity is demonstrated. Standard operating procedures and quality assurance/quality control (QA/QC) procedures for this task are outlined in Kszos et al. (1989).

\subsubsection{Ambient toxicity monitoring (Subtask 1b)}

Subtask $1 \mathrm{~b}$ will monitor ambient water toxicity of Miichell Branch and Poplar Creek using 7-d fathead minnow and Ceriodaphnia toxicity tests similar to those described in Sect. 2.1.1. Six sites which correspond closely to those used in the instream monitoring task (Sect. 2.4) will be sampled on Mitchell Branch (Table 1 and Figs. 1 and 2). These include a site at the NPDES weir above the confluence with Poplar Creek at MIK 0.12 and five sites upstream (MIK 0.45, MIK 0.54, MIK 0.71, MIK 0.78, and MIK 1.43; Fig. 2). The site at MIK 1.43 is above K-25 Site operations and will serve as a reference. The previous BMAP included a site at MIK 1.10; this site was moved to MIK 0.78 in the new BMAP to coincide with the benthic macroinvertebrate sampling site.

The Poplar Creek and Clinch River sites are shared with the CRRI (R. B. Cook et al., unpublished data) and include (1) PCK 18.2, an upstream reference site; (2) PCK 8.2 above the confluence with Mitchell Branch; (3) PCK 6.9 below the confluence with Mitchell Branch; (4) PCK 4.7 below Outfall 011; (5) PCK 1.6 below the K-25 Powerhouse; and (6) CRK 15.0 below the confluence of Poplar Creek and Clinch River (Fig. 1). Each of these sites will be tested quarterly for the first year with both species. Samples from Mitchell Branch will be daily grabs. Samples from the Clinch River and Poplar Creek will be three grab samples collected over the 7-d test period. Every effort will be made to evaluate Poplar Creek and Mitchell Branch sites concurrently. When Outfall 011 is moved to the Clinch River, testing at PCK 4.7 will be discontinued. The results obtained from the first four quarterly tests will be evaluated to determine whether sampling frequency and/or number of sites and/or number of test species should be modified.

\subsubsection{Storm drain survey (Subtask 1c)}

During the initial BMAP, SD 170 , SD 180 , and SD 190 were periudically evaluated. During this time, chlorine was occasionally identified as a toxicant; removal of chlorine with sodium thiosulfate eliminated the toxicity. However, removal of chlorine from the effluent with sodium thiosulfate did not always remove the toxicity (Table 2). Thus, toxicity monitoring of the storm drains will be conducted on a more systematic basis during the first year. Effluent from SD 170, SD 180, and SD 190 will be evaluated every other month for a minimum of one year with Ceriodaphnia and Microtox ${ }^{\bullet}$. Following this 
characterization phase, the K-25 Site and Oak Ridge National Laboratory (ORNL) representatives will meet to discuss results and alternatives.

Table 2. Fraction of toxicity tests of effluent discharged from storm drains 170, 180, and 190 showing toxicity from a source other than chlorine

\begin{tabular}{|c|c|c|c|}
\hline Storm drain & Year & Fathead minnow & Ceriodaphnia dubia \\
\hline Total & $\begin{array}{l}1988 \\
1989 \\
1990 \\
1991 \\
1992\end{array}$ & $\begin{array}{l}1 / 3 \\
0 / 1 \\
0 / 3 \\
0 / 1 \\
0 / 2 \\
1 / 10\end{array}$ & $\begin{array}{l}2 / 3 \\
2 / 2 \\
2 / 3 \\
2 / 2 \\
3 / 3 \\
11 / 13\end{array}$ \\
\hline . & $\begin{array}{l}1988 \\
1989 \\
1990 \\
1991 \\
1992\end{array}$ & $\begin{array}{l}0 / 2 \\
0 / 1 \\
1 / 3 \\
1 / 1 \\
1 / 2 \\
3 / 9\end{array}$ & $\begin{array}{l}0 / 2 \\
0 / 1 \\
2 / 3 \\
0 / 2 \\
2 / 3 \\
4 / 11\end{array}$ \\
\hline Total & $\begin{array}{l}1988 \\
1989 \\
1990 \\
1991 \\
1992\end{array}$ & $\begin{array}{l}1 / 2 \\
\text { NT } \\
0 / 3 \\
0 / 1 \\
0 / 1 \\
1 / 7\end{array}$ & $\begin{array}{l}1 / 2 \\
1 / 1 \\
0 / 3 \\
1 / 2 \\
2 / 3 \\
5 / 11\end{array}$ \\
\hline
\end{tabular}

Note: The quantities listed are the number of toxicity tests in which the no-observed-effect concentration (NOEC) for Ceriodaphnia or fathead minnows was $<100 \%$ as compared with the total number of tests conducted for storm drains 170, 180, and 190. Tests included are those in which the effluent was either dechlorinated or concentrations of total residual chlorine ranged from 0.0 to $0.09 \mathrm{mg} / \mathrm{L}$. (The NOEC is the concentration that causes no reduction in survival or reproduction of Ceriodaphnia, or survival or growth of fathead minnows.)

Because storm drains are now the major contributor to flow in Mitchell Branch (process water is discharged to Poplar Creek), Category III outfalls that discharge to Mitchell Branch and that are accessible will be surveyed during the first two years.

\subsection{BIOACCUMULATION MONITORING (TASK 2)}

\subsubsection{Introduction}

During the period 1987-91, bioaccumulation monitoring for the K-25 Site BMAP focused on the extent of contamination in aquatic biota in Mitchell Branch and nearby waters of Poplar Creek. To address modifications cited in the new NPDES permit, the 
bioaccumulation monitoring task has increased in scope (1) to evaluate potential biological contamination in other aquatic habitats associated with the K-25 Site and (2) to assess contamination in the terrestrial environment.

The bioaccumulation monitoring task has four primary objectives: (1) identify contaminants that accumulate in biota, (2) determine the degree of contamination, (3) identify and evaluate contaminant sources, and (4) evaluate spatial and temporal changes in biotic contamination to evaluate the effectiveness of remedial actions. The

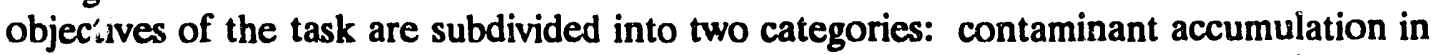
aquatic biota (Subtask 2a), and contaminant accumulation in terrestrial biota (Subtask 2b).

\subsubsection{Contaminant Accumulation in Aquatic Biota (Subtask 2a)}

\subsection{Overview}

In the vicinity of the K-25 Site, a variety of contaminants have been detected in water (Loar et al. 1981, Scheib 1987, Kornegay et al. 1991) and sediment (Loar et al. 1981, Elwood 1984, Ashwood et al. 1986, Kornegay et al. 1991). However, many of these contaminants are not readily bioavailable. At sites routinely monitored near the K-25 Site, only mercury and PCBs bioaccumulate to significant levels in fish. Mercury concentrations in fish from Poplar Creek have averaged $0.3-0.7 \mu \mathrm{g} / \mathrm{g}$, depending on such variables as specific location, species, and time of year, with relatively little change from 1977 to the present (Loar et al. 1981; Elwood 1984; TVA 1985; M. J. Peterson, unpublished data; G. R. Southworth, unpublished data; Cook 1992). Significant PCB contamination has also been documented in Poplar Creek fish, particularly in lipid-rich species (e.g., channel catfish and carp), where some individuals collected since 1977 have had concentrations in excess of the $2.0 \mu \mathrm{g} / \mathrm{g}$ action limit set by the U.S. Department of Agriculture Food and Drug Administration (FDA) (Loar 1981, FDA 1984a, TVA 1985, J. G. Smith, unpublished data). The mean concentration of PCBs in channel catfish collected from Poplar Creek during the period 1988-91 $(\sim 0.8 \mu \mathrm{g} / \mathrm{g}, \mathrm{G}$. R. Southworth, unpubiished data) supports the precautionary fish-consumption advisory currently in effect for this reach of Watts Bar Reservoir (TDEC 1992).

Bioaccumulation monituring efforts for the K-25 Site BMAP (M. J. Peterson, unpublished data) focused on the accumulation of contaminants in resident fish and caged clams in Mitchell Branch. The importance of Mitchell Branch as a source of contamination to Poplar Creek was also evaluated. The results of BMAP bioaccumulation monitoring conducted from 1987 to 1992 indicate that mercury and PCBs accumulate in both Poplar Creek and Mitchell Branch biota to levels significantly above background levels (M. J. Peterson, unpublished data). Accumulation of PCBs in redbreast sunfish (Lepomis auritus) and caged clams (Corbicula fluminea) in Mitchell Branch was substantial; some individual fish and clam composite samples had PCB concentrations above the FDA action limit (FDA 1984a). Although Mitchell Branch is a likely source of PCBs to biota in Poplar Creek, the PCB contribution from Mitchell Branch appears small relative to other possible sources (i.e., EFPC and Bear Creek inputs and Poplar Creek sediments). 
Mercury was clearly elevated in Mitchell Branch fis..,; however, these concentrations were well below the FDA and EPA action level of $1.0 \mu \mathrm{g} / \mathrm{g}$ (FDA 1984b, EPA 1990). The close proximity of the Mitchell Branch site to Poplar Creek, coupled with the similar mercury concentrations (af:er size adjustment) in fish from the two systems, suggested that fish collected from Mitchell Branch may have migrated from mercury-contaminated Poplar Creek. The importance of Mitchell Branch as a source of mercury contamination to its own biota, or to biota in downstream waters, is not yet known.

Although elevated concentrations of some other contaminants have been detccted in aquatic biota near the K-25 Site, most of these concentrations were extremely low or not detected consistently by follow-up monitoring. Fish from Mitchell Branch and Poplar Creek have had concentrations of some metals that exceeded those observed in fish from reference streams (Loar et al. 1981; TVA 198;; G. R. Southworth, unpublished data; Cook et al. 1992). On average, however, the concentrations in these fish were below concentrations used by EPA (EPA 1990) and others (Hoffman et al. 1984, Travis et al. 1986) to identify contaminant levels that pose no threat for human consumption. Asiatic

clams placed in Mitchell Branch had detectable levels of some phthalates in 1987 and some polycyclic aromatic hydrocarbons (PAHs) in 1990 (G. R. Southworth, unpublished data). Most of the organic pollutants monitored in Poplar Creek fish were not substantially elevated in 1984 (TVA 1985), 1989 (Cook et al. 1992), and 1990 (J. M. Loar, unpublished data, 1991), with the exception of PCBs and some chlordane isoiners. Recent evidence suggests that chlordane contamination in fish is an omnipresent problem in many East Tennessee waters (TVA 1990, TDEC 1992). The extent to which DOE facilities may be a source of the observed chlordane contamination is unknown.

\subsubsection{Sampling Design and Rationale}

In order to evaluate the extent of contamination in aquatic biota associated with the K-25 Site, a comprehensive bioaccumulation monitoring plan will be implemented that will encompass Mitchell Branch, Poplar Creek and selected tributaries, and the Clinch River (Figs. 1 and 2). The plan was designed in conjunction with other bioaccumulation monitoring studies being conducted near the K-25 Site, including the Y-12 Plant and Oak Ridge National Laboratory BMAPs, the K-901 Operable Unit Remedial Investigation, and the Clinch River Remedial Investigation. Effective coordination with these programs will minimize costs and avoid unnecessary duplication of sample collection and analysis.

The aquatic bioaccumulation task has two general components: an initial "screening" component and a routine "tracking" component. The screening component is designed to be a one-time scoping study conducted during the first year to assess the bioaccumulation of a wide range of contaminants at various locations. The scoping study will be conducted at sites where the contaminants of concern in aquatic biota are unknown (pond sites, PCK 18.2), or where past studies of some contaminants have obtained equivocal results (MIK 0.2, PCK 1.6). Depending on fish availability, a suite of contaminants (Table 3) will be monitored in aquatic biota from tributaries of Poplar Creek (including MIK 0.2 and the K-1007-P1, K-1007-P5, and K-710A ponds (Figs. 2 and 3) and from two sites on Poplar Creek, one upstream (PCK 18.2) and one downstream (PCK 1.6) of all known K-25 inputs to Poplar Creek (Fig. 1). If the results of the scoping study indicate that contaminant concentrations in fish approach or exceed commonly cited human health 
threshold limits (FDA 1984a, 1984b; Hoffman et al. 1984; Travis et al. 1986; EPA 1990), routine monitoring will be initiated to more thoroughly track spatial and temporal changes in those contaminant levels. Because previous studies of some screening sites have already identified mercury and PCB contamination, these two contaminants will be routinely monitored in fish at PCK 18.2, PCK 1.6, and MIK 0.2 as part of the tracking study (see following).

Table 3. Summary of the proposed monitoring plan for aquatic biota, listing the species and analytes for each of nine sampling sites

\begin{tabular}{|c|c|c|c|c|c|}
\hline \multirow[b]{2}{*}{ Site/Location } & \multicolumn{5}{|c|}{ Analytes } \\
\hline & Mercury & Other metals & PCBs & Pesticides & $\mathrm{OPP}^{\mathrm{a}}$ \\
\hline $\begin{array}{l}\text { Poplar Creek } \\
\text { PCK 18.2, upstream of all DOE } \\
\text { inputs }\end{array}$ & BG & BG & BG & & $\mathrm{AC}$ \\
\hline $\begin{array}{l}\text { PCK 8.2, upstream of Mitchell } \\
\text { Branch, downstream of EFPC }\end{array}$ & BG & & BG & & \\
\hline $\begin{array}{l}\text { PCK 6.9, downstream of } \\
\text { Mitchell Branch }\end{array}$ & BG & & $\mathrm{BG}, \mathrm{CC}$ & $\mathrm{CC}$ & \\
\hline $\begin{array}{l}\text { PCK 1.6, downstream of all K-25 } \\
\text { inputs to Poplar Creek }\end{array}$ & BG & BG & BG & & $\mathrm{AC}$ \\
\hline $\begin{array}{l}\text { Clinch River } \\
\text { CRK } 15.0 \text {, downstream of all } \\
\text { DOE inputs }\end{array}$ & BG & & $\mathrm{CC}$ & $\mathrm{CC}$ & \\
\hline $\begin{array}{l}\text { K-25 Tributary Sites } \\
\text { MIK 0.2, downstream section of } \\
\text { Mitchell Branch }\end{array}$ & RB & RB & RB & & $\mathrm{AC}$ \\
\hline $\begin{array}{l}\mathrm{K}-1007-\mathrm{P} 1 \text {, large pond south of } \\
\text { the main plant area }\end{array}$ & BG & BG & LMB & & $A C$ \\
\hline $\begin{array}{l}\text { K-1007-P5, small pond upstream } \\
\text { of P1 pond, near SD } 130\end{array}$ & BG & BG & LMB & & \\
\hline $\begin{array}{l}\text { K-710A narrow pond, in the } \\
\text { powerhouse area }\end{array}$ & BG & BG & LMB & & $\mathrm{AC}$ \\
\hline
\end{tabular}

${ }^{a}$ Organic priority pollutants.

Note: Nomenclature for the stream sites (e.g., MIK 0.2) refers to the distance (in kilometers) above the stream mouth. $B G=$ bluegill sunfish (Lepomis macrochinus), $\mathrm{RB}=$ redbreast sunfish $(L$ auritus), $\mathrm{LMB}=$ largemouth bass (Micropterus salmoides), $\mathrm{CC}=$ channel catfish (Ictalurus punctatus), and $\mathrm{AC}=$ asiatic clam (Corbicula fluminea). 


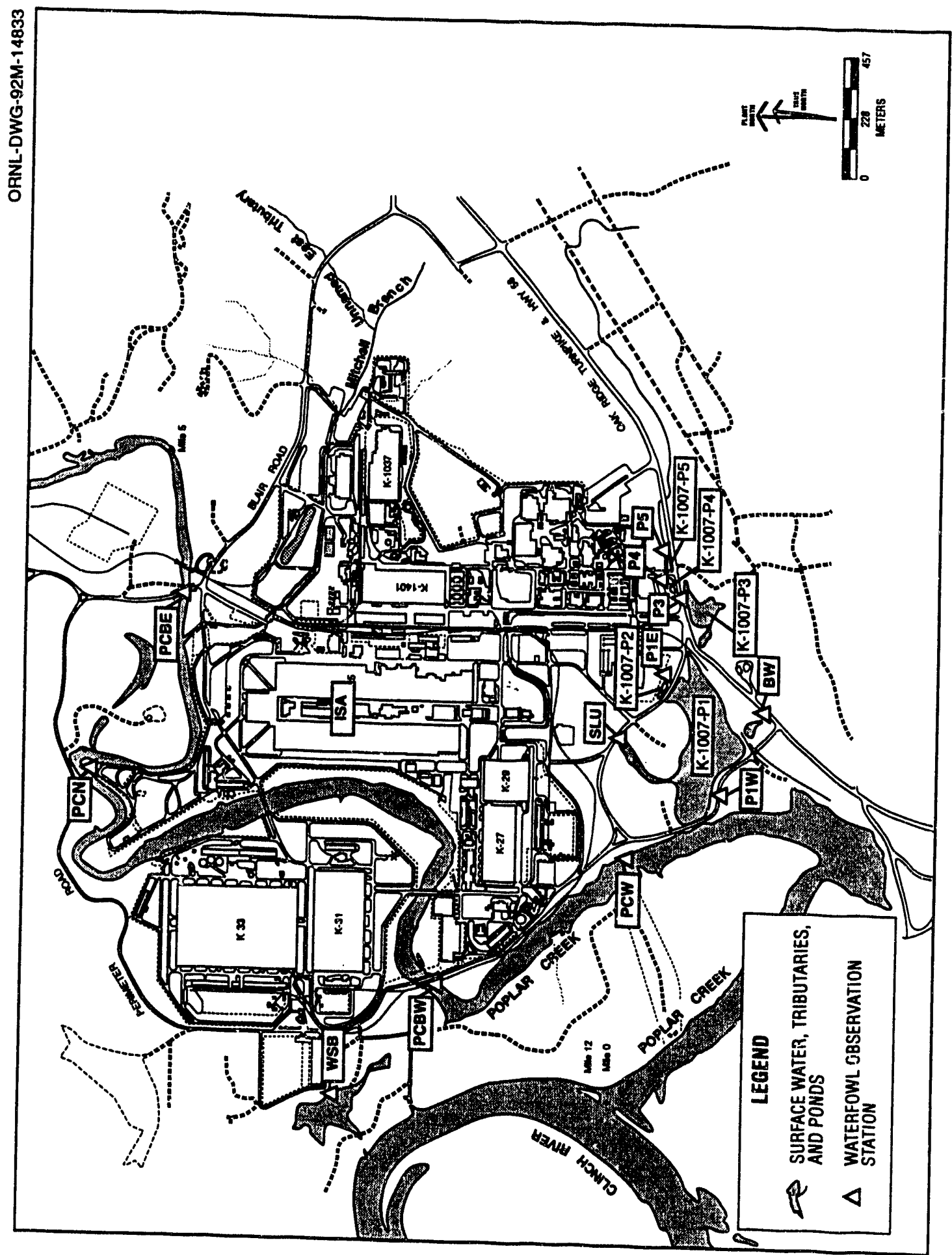

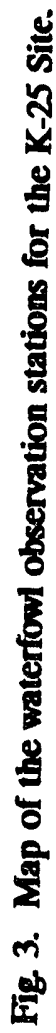


Ponds were chosen for bioaccumulation monitoring based on evidence of water (Scheib 1987) and sediment (Ashwood et al. 1986) contamination and because of the proximity of the sites to potential contaminant sources (e.g., effluents, storm drains, burial grounds, ash piles). The seiected sites have not been the focus of previous or current bioaccumulation studies. Tie sediment-sontaminated K-901A pond is not addressed in this plan because a bioaccumulation study will be initiated in spring 1993 as part of the K-901 Operable Unit remedial investigation (Blaylock and Frank 1992). Bioaccumulation monitoring will not be conducted at the $\mathrm{K}-1515$ pond because (1) there is low potential for significant contaminant inputs to the pond and (2) previous monitoring of sediment at the site revealed no significart contamination (Ashwood et al. 1986). Although ${ }^{137} \mathrm{Cs}$ has been detected in K-1515 pnnd sediment (Ashwood et al. 1986; CRRI, unpublished data for 1992), the low level of contamination in sediment, coupled with the low bioaccumulation potential of ${ }^{137} \mathrm{Cs}$ when bound to local sediment types, strongly suggests that the K-1515 sediment is uniikely to be a significant source of ${ }^{137} \mathrm{Cs}$ to fish.

The primary objectives of mercury and PCB tracking near the K-25 Site have been to detect changes in biological contamination over time as a possible result of remedial actions and to help evaluate contaminant sources. Routine monitoring of mercury and PCB contamination in resident fish from sites on Mitchell Branch (MIK 0.2), Poplar Creek (PCK 8.2, PCK 6.9, and PCK 1.6), and the Clinch River (CRK 15.0), will continue as in previous years (see Table 1 and Figs. 1 and 2 for site locations). In addition, a site on Poplar Creek upstream of all the K-25 Site and EFPC inputs and upstream of reservoir back-water effects will also be monitored for mercury and PCBs (PCK 18.2). Monitoring at sites on Poplar Creek both upstream and downstream of the major tributary inputs should ensure that the impact of various inputs to bioaccumulation in Poplar Creek can be adequately evaluated. Initially, the sites will be monitored annually, but this frequency may be modified if changes in contaminant conditions warrant. For example, monitoring at a site may be discontinued if the monitoring results consistently reveal no evidence of contamination.

\section{Species selection and sampling methodology}

Resident fish and caged clams will again be utilized to monitor waters near the K-25 Site. There are several advantages of using fish as a monitoring tool: (1) they are eaten directly by humans and so can provide a direct measure of risk to human health; (2) some species have limited ranges and thus can be used to identify biologically available contaminant sources; (3) larger fish are near the top of the aquatic food chain and likely represent the maximum level of biotic contamination at a site; and (4) fish are abundant in most areas and can be readily collected.

Despite these general advantages, no single fish species is likely to be optimal as a monitoring tool. The species population most likely to represent the maximum level of PCBs at a site is one that has large, old, individuals with relatively high intrarnuscular lipids, such as channel catfish, carp, and largemouth bass. However, the PCB burden in these fish often represent years of exposure over a wide ranging area. Thus, species such as sunfish, which tend to be more short lived and sedentary, are better suited for tracking studies designed to assess recent bioaccumulation at the collection site. Caged Asiatic 
clams (Corbicula fluminea) will be used because they have been shown to be effective monitors of organic compounds, such as PAHs, that are rapidly metabolized and excreted (and therefore not accumulated) by fish.

Bluegill sunfish (Lepomis macrochirus) will be the primary species for tracking mercury and PCB contamination (Table 3). In Mitchell Branch, where bluegill are not abundant, redbreast sunfish ( $L$. auritus) will be used. To statistically evaluate spatial and temporal changes in bioaccumulation, eight fish will be collected from each site and analyzed individually for these contaminants. To evaluate the maximum level of PCB and pesticide contamination likely in biota from Poplar Creek and the Clinch River, channel catfish will be collected as part of an on-going off-site monitoring program conducted jointly by the Y-12 Plant, K-25 Site, and ORNL BMAPs.

The fish species of choice for the one-year contaminant screening study will depend, to a large degree, upon species availability. At the tributary pond sites (K-1007-P1, $\mathrm{K}-1007-\mathrm{P5}$, and K-710A), largemouth bass and bluegill would be suitable species for PCBs and metal analysis, respectively, and are the two species most likely to be collected in adequate numbers. Bluegill will be used to assess metal contamination at the two screening sites on Poplar Creek (PCK 1.6 and PCK 18.2), and redbreast sunfish will be used to monitor metal contamination in Mitchell Branch (MIK 0.2). Caged asiatic clams will be used to monitor organic priority pollutants at MIK 0.2, PCK 18.2, PCK 1.6, K-1007-P1, and K-710A (Table 3). Because statistical comparisons are not required for screening studies where contaminant identification is the primary objective, fewer samples are needed. Therefore, four individual fish samples and/or composite samples (e.g., 10-20 clams per analytical sample), will be used to identify the contaminants of concern at most sites.

If possible, only fish of a size likely to be taken by sport fisherman ( $>40 \mathrm{~g}$ for sunfish, $>400 \mathrm{~g}$ for catfish and largemouth bass) will be collected. Upon return to the laboratory, the fish will be weighed, measured, and filleted. At each site, the caged asiatic clams will be exposed for four weeks, after which they will be processed by removing the soft tissue from each individual. All samples will be stored at $-20^{\circ} \mathrm{C}$ before analysis by the ORNL Analytical Chemistry Division using EPA-approved protocols. Quality assurance will be maintained using a combination of (1) blind duplicate analyses, (2) split sample analyses among various laboratories, (3) analyses of biological reference standards and uncontaminated fish, and (4) analyses of known spiked quantities (Southworth and Peterson 1992).

\subsection{Contaminant Accumulation in Terrestrial Biota (Subtask 2b)}

\subsubsection{Overview}

Biological monitoring programs typically focus on aquatic organisms because they are the ones directly exposed to waterborne contaminants. However, many terrestrial species obtain a substantial portion of their diet from aquatic sources; and some terrestrial species, especially waterfowl, spend a significant portion of their lifetime in the water. For contaminants that bioaccumulate and are concentrated by passage up the food chain, terrestrial predators, especially piscivorous animals, may receive a higher dose than would 
be predicted by only measuring bioaccumulation in the aquatic system. Previous BMAP data for the K-25 Site indicate that two contaminants with a high bioaccumulation potential, mercury and PCBs, are found at elevated levels in Mitchell Branch and Poplar Creek (Sect. 2.2.2.1). Thus, some terrestrial organisms that consume biota from these streams may be receiving a significant dose of these contaminants.

To assess the potential magnitude of exposure within the terrestrial ecosystem, this subtask will evaluate two terrestrial species known to accumulate contaminants from the aquatic system.

A waterfowl survey component will determine the contribution of K-25 Site contamination sources to migratory waterfowl populations and will monitor the size and movement of the Canada goose subpopulation at the K-25 Site. This component would contribute to an ongoing reservation-wide waterfowl monitoring program. The raccoon bioaccumulation component, which is also an extension of a reservation-wide monitoring effort, will evaluate the feasibility of using raccoons to assess whether K-25 Site-derived contaminants are adding to the exposure of terrestrial biota. A third component of Subtask $2 \mathrm{~b}$, fish whole-body analysis, will provide information regarding potential effects on sensitive terrestrial piscivores from consumption of contaminated prey. The latter two studies will be conducted for one year; if sufficient contaminant exposure exists (see discussion in last four paragraphs of Sect. 2.2.3.3 for a detailed exploration of how this determination will be made), additional investigations will be initiated.

\subsubsection{Waterfowl Studies}

Waterfowl spend a significant amount of time in the water, and they are exposed to many waterborne contaminants simply through the ingestion of water. Moreover, some species forage on macrophyte and algae in the water column and on benthic organisms in the sediment. Because of their mobility, waterfowl can be direct vectors of contaminants from aquatic habitats on ORR to hunters who harvest them for food in areas adjacent to reservation.

As part of the ORNL BMAP, a study was initiated in 1987 to assess the uptake of radionuclides by migratory waterfowl on White Oak Lake and other waste disposal areas. This study was later expanded to include (1) assessment of nonradioactive contaminants in waterfowl; (2) weekly census of waterfowl use of lakes, ponds, impoundments, and streams on ORR and selected off-site areas; and (3) annual marking/banding of Canada geese to estimate population size and assess movement patterns. Aquatic habitats on and near the K-25 Site were added to the reservation-wide waterfowl study in October 1988.

The waterfowl survey includes routine monitoring of Canada geese and other waterfowl located on ORR and nearby areas on the Clinch River (see Fig. 3 for K-25 Site locations). The K-25 Site portion of this study includes the capture of Canada geese during the molting season (late June to early July) and the placing of leg bands and throat collars with identifying numbers on the birds. Geese with ident ifying throat collars are monitored routinely to determine the movement of individuals on and off ORR and to provide data for estimating the size and growth of the population. 
The second portion of this study involves the collection of birds for contaminant analyses. During the migratory season, approximately five waterfowl from each of several locations at the K-25 site will be harvested, and their tissues will be analyzed for radionuclides and other contaminants, including $\mathrm{PCBs}, \mathrm{Hg}, \mathrm{Cr}, \mathrm{Ni}, \mathrm{Cd}$ and $\mathrm{Pb}$. Potential collection points at the K-25 Site are K-1007-P1 pond, K-901A pond, and Poplar Creek embayment downstream from the K-1007-P2 pond discharge. The resident wood duck population on Poplar Creek will be included in the sampling program because of their potential to accumulate contaminants during their early developmental period.

All waterfowl survey and sampling activities will be conducted in accordance with the BMAP waterfowl QA Plan (Blaylock et al. 1992).

\subsubsection{Raccoon Bioaccumulation Monitoring}

Raccoons have been added to the ORNL BMAP because they serve as surrogates for sensitive terrestrial species that forage in aquatic habitats. Populations of sensitive species (e.g., mink) are too small to permit satisfactory statistical evaluation. Raccoons are abundant, relatively easy to collect, and similar in physiology to more sensitive mammalian piscivores. An ongoing study funded by CRRI is evaluating the bioaccumulation of mercury and PCBs in piscivorous birds (specifically, great blue herons) that forage around the K-25 Site.

The purpose of this component of Subtask $2 b$ is to evaluate the feasibility of using raccoons for monitoring of K-25 Site-derived mercury and $\mathrm{PCBs}$ within the terrestrial ecosystem. A 1-year trial program is planned to determine whether sufficient information (see Sect. 2.2.3.3) can be obtained from raccoons to justify continued monitoring as part of the long-term K-25 Site BMAP.

Ten raccoons will be collected from the vicinity of the K-25 Site, especially the area adjacent to Poplar Creek downstream of Mitchell Branch. Hair samples will be analyzed for mercury, and biopsy samples of fat will be analyzed for PCBs. A second set of ten raccoons will be collected from Foplar Creek and EFPC upstream from the K-25 Site. These raccoons will be sampled and analyzed in the same manner as those from the K-25 Site.

All raccoon trapping and sample collection will be performed in accordance with the latest revision of the standard operating procedure (T. L. Ashwood, unpublished data).

The goal of this component of Subtask $2 \mathrm{~b}$ is to determine whether contamination from the K-25 Site is being taken up by a terrestrial predator that consumes aquatic prey. We propose to use a two-pronged test to make this determination.

First, mercury and PCB concentrations in raccoons from the K-25 Site will be compared with concentrations in raccoons from an uncontaminated reference site (reference site raccoons are being sampled as part of the ORNL BMAP). If this comparison reveals no difference in contaminant levels between the two sample groups, then there is strong evidence that raccoons are not taking up contamination that is derived from the K-25 Site. There would then be no point in continuing this component of the 
bioaccumulation monitoring task. On the other hand, if the raccoons from the K-25 Site are demonstrably more contaminated than those from the reference site, then there is evidence that mercury and PCBs are being accumulated by terrestrial biota in the vicinity of the K-25 Site.

The second part of the test will compare PCB and mercury concentrations in raccoons from the K-25 Site with concentrations in raccoons from an area located upstream. This second comparison may provide evidence as to whether the source of PCBs and mercury is from the K-25 Site or from upstream sources on EFPC and its tributary, Bear Creek. This comparison is unlikely to be resolvable in a single year because of two factors: (1) variability in contaminant concentrations within a sample group is likely to be high because of the wide variety in food habits among individual raccoons; and (2) concentrations of PCBs and mercury in fish from the Bear Creek and EFPC watersheds are high. The combination of these two factors means that the sample size of ten is likely to be insufficient to identify significant differences. Obtaining a sample size of much greater than ten in a single year would be difficult given previous experience with trapping raccoons in the EFPC floodplain. Hence, time series analysis of data over a number of years may be necessary to determine whether a difference exits between the two populations. A further confounding factor may be overlap between the upstream and downstream populations. Radio-tracking data will be gathered to determine whether overlapping of population occurs.

Results of the whole-body analyses of stonerollers (Sect. 2.2.3.4) are also likely to play a part in the decision regarding duration of the raccoon sampling component. If concentrations of contaminants in stonerollers are high enough to cause deleterious effects in sensitive terrestrial predators (i.e., mink), then continued monitoring of contaminant levels in raccoons is advisable until such time as remedial actions result in decreases of those contaminant levels.

In summary, the raccoon monitoring component of Subtask $2 \mathrm{~b}$ will terminate after one year if there is no measurable difference in PCB and mercury concentrations between raccoons from the $\mathrm{K}-25$ Site and those from an uncontaminated reference site. If raccoons from the K-25 Site are more contaminated than reference site raccoons, raccoon monitoring will continue until either (1) sufficient data are available to demonstrate that K-25 Site raccoons are no more contaminated than raccoons from upstream, or (2) contaminant concentrations in K-25 Site raccoons drop to reference site levels.

\subsubsection{Whole-Body Analyses of Representative Prey Fish}

A one-time sampling of representative fish typically consumed by terrestrial predators will be conducted. Other K-25 Site bioaccumulation studies focus on analyses of mercury and PCBs in fish fillets because such samples (1) are representative of human exposure to the contaminants and (2) can be used to assess differences in contaminant bioaccumulation among different sites. However, terrestrial predators tend to consume

\footnotetext{
"The lowest observed effects level for both PCBs and methylmercury in mink food is 0.5 ppm (MacIntosh et al. 1992).
} 
the entire fish rather than just the fillet, so the whole-body burden of the fish is more representative of the dose received by these animals. Moreover, the species used in Subtask $2 \mathrm{a}$ (Table 3) are not the most representative species for consumption by terrestrial predators, particularly avian predators. Minnows, especially stonerollers (Campostoma anomalum), represent the prey of choice for avian predators and are likely to be more representative of the prey consumed by mammalian predators. This is especially important because of the trophic position of stonerollers, which forage on periphyton; sunfish tend to feed primarily on benthic invertebrates.

Ten stonerollers will be collected from Poplar Creek downstream of Mitchell Branch, and, if possible, ten stonerollers will be collected from K-1007-P1 pond. Because the purpose of this investigation is to determine only the total body burden of a food source, the collection of stonerollers from a reference stream is unnecessary. Each fish will be homogenized, and representative aliquots will be analyzed for PCBs and mercury.

Results from this sampling will be used to predict the doses of mercury and PCBs to piscivorous wildlife. This information will supplement the raccoon bioaccumulation monitoring by providing information that can be used directly to assess the risk to sensitive terrestrial species.

\subsection{ASSESSMENT OF FISH HEALTH (TASK 3)}

\subsubsection{Introduction}

This task involves the use and application of bioindicators to evaluate the effects of water quality and other environmental variables on fish population health in lower Mitchell Branch, lower Poplar Creek, the lower sections of the Clinch River, and a selected pond on the K-25 Site. Bioindicators have been used since 1988 to evaluate the health of redbreast sunfish in lower Mitchell Branch. Bioindicator studies during 1988-90 demonstrated that the biochemical, physiological, and overall health of this species has been impaired as evidenced by (1) elevated activity of liver detoxification enzymes, (2) gill and liver dysfunction, (3) pathological changes in the liver, and (4) abnormal size-frequency distribution and age structure of the fish population.

Because preliminary studies in Mitchell Branch during 1986 and 1987 revealed no fish species of sufficient size and quantity to support a biological indicator task, the initial BMAP (Loar et al. 1992b) was developed with the understanding that sunfish could be collected from uncontaminated streams, introduced into Mitchell Branch, and subsampled over time for bioindicator analysis. After the plan was submitted and approved by the Tennessee Department of Health and Environment (presently the TDEC), however, adequate numbers and sizes of naturally occurring redbreast sunfish populations were found in lower Mitchell Branch to implement the bioindicator task without introducing fish from other streams.

Biological indicators have been used successfully in a variety of aquatic systems to (1) evaluate the effect of water quality and other environmental variables on the health of fish populations and communities, (2) determine the effectiveness of past and ongoing 
remedial actions on these fish communities, and (3) aid in the identification of causative agents or mechanisms responsible for any observed effects on biological communities. An understanding of such effects and mechanisms allows more reliable and defensible decisions about the need or advisability for specific remedial actions.

The major aquatic systems where bioindicators have been used to identify and evaluate health effects in fish populations and communities include (1) EFPC as a component of the Y-12 Plant BMAP (Loar et al. 1992c; S. M. Adams, unpublished data; Adams 1990a); (2) White Oak Creek as a component of the ORNL BMAP (J. M. Loar, unpublished data, 1989, 1990, 1991, 1992) (Loar et al. 1992c); (3) Pigeon River in North Carolina and Tennessee, which receives pulp and paper effluents (Adams et al. 1992a); and (4) Hartwell Reservoir in South Carolina and Georgia which contains fish contaminated with high levels of PCBs (Adams and Greeley 1991). Other systems currently being evaluated through bioindicator studies are coastal areas of South Carolina (influenced by paper mills and other industries); natural lakes on Cape Cod, Massachusetts (potentially contaminated with PAHs); and the Watts Bar Reservoir system, including the Clinch River and Poplar Creek, which are components of the CRRI sampling and analysis plan. Adams' (1990b) recently published book on biological indicators provides more details about use and application of bioindicators for assessing the effects of contaminants on fish populations.

One primary advantage of using bioindicators in biological monitoring programs is that they can be applied within a holistic or integrative framework to evaluate the effects of water quality and other environmental variables on fish community health (Adams et al. 1989; Adams 1990b). This integrative approach has several advantages over the measurement of individual response variables for investigating the relationship between fish health and environmental stressors. Stress effects on fish cannot be adequately evaluated by measurement either of a single stress response or of several responses displayed at only one level of biological organization because the sensitivity of fish to stress is not constant across all stressors (Heath 1987). Because no single variable is adequate for prediction of population and community-level changes (Capuzzo 1985), no single method or index can provide all the integrative information necessary to understand the condition of a fish population or community (Cairns and Van der Schalie 1980). Moreover, single response variables can cause problems in interpretation. For example, single response measurements are often affected by such variables as the environmental history, developmental state, reproductive condition, and nutrition of the organism being studied (Sastry and Miller 1981). In addition, physiological compensation by organisms can affect interpretation of stress responses (Hazel and Prosser 1974). Therefore, given the limitations of using individual measurements to evaluate the health of fish, an integrative approach will be employed to more accurately reflect and evaluate the overall condition and health of key fish populations in Mitchell Branch and other aquatic systems that are or have the potential to be affected by K-25 Site operations.

The sampling design plan for the bioindicators task incorporates some major modifications from the original plan. First, in collaboration with CRRI (R. B. Cook et al., unpublished data), sampling will be conducted periodically at selected sites in the Clinch River and in Poplar Creek near the K-25 Site. In addition, fish will be collected from the K-1007-P1 pond to assess potential contaminant effects on key fish species. As one 
component of the bioindicators task, a reproductive effects subtask will be included in the new BMAP.

\subsubsection{Bioindicators (Subtask 3a)}

The principal components of the sampling design proposed for the bioindicators subtask are (1) the response parameters to be measured, (2) sampling locations, (3) target species to be collected, and (4) sampling frequency.

\subsection{Bioindicator Response Parameters}

The original BMAP for the K-25 Site (Loar et al. 1992b) included a wide range of selected indicators to be measured at several levels of biological organization. Because relatively few studies had been conducted on field applications of bioindicators in 1986 when the initial BMAP for the K-25 site was developed, the basic sampling strategy at that time was to measure a wide suite of bioindicators representative of several levels of biological organization. After 2 years of monitoring, the original suite of indicators was evaluated and a subset of these indicators was chosen for long-term biomonitoring. The groups of bioindicators selected for routine monitoring in Mitchell Branch are detoxification enzymes, metabolic dysfunction, histopathological condition, condition indices, bioenergetic function, feeding and nutrition, and population-level indices. The specific indicators that will continue to be measured in each group are described in the following paragaraphs and summarized in Table 4. All Quality Assurance Documentation and procedures related to the biological indicators task are described in the BMAP Quality Assurance Plan (Adams and Greeley 1992).

\section{Indicators of contaminant exposure}

The activity or levels of liver detoxification enzymes are used to indicate exposure to various contaminants such as PCBs, PAHs, and pesticides (Chamber and Yarbrough 1976, Stegeman and Kloepper-Sams 1987). With some contaminants such as PAHs, detoxification enzymes may function as a diagnostic indicator for more serious effects on organisms because detoxification enzyme activity is required for activation to ultimate carcinogens. The lag time between exposure to a contaminant and the biological response is typically short (hours to days), with the response generally persisting throughout the exposure and for some time thereafter (days to weeks) (Fig. 4). As a proven indicator of contaminant exposure, the activity of ethoxyresorufin $O$-deethylase (EROD) will be measured in the liver of fish sampled from sites in Mitchell Branch, Poplar Creek, Clinch River, and the K-1007-P1 pond. The concentration of microsomal protein in hepatic tissue will be quantified not only to serve as a standard for reporting EROD activity but also to indicate possible microsomal proliferation due to contaminant exposure. EROD and microsomal protein were the main indicators of toxicant exposure as identified in other bioindicator studies (J. M. Loar, unpublished data, 1989, 1990, 1992; Loar et al. 1992a; Adams and Greeley 1991; Adams et al. 1992a, 1992b). 


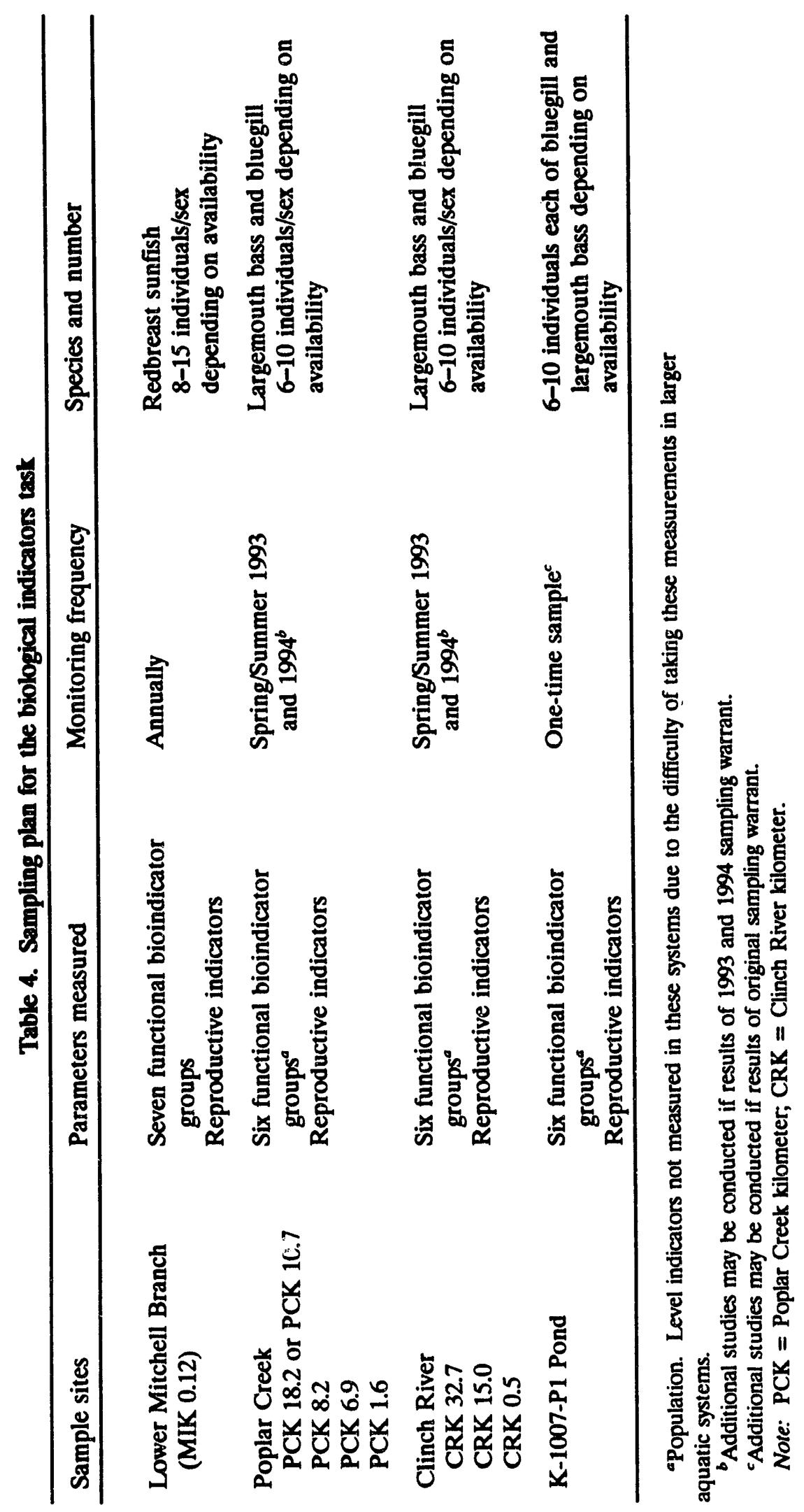




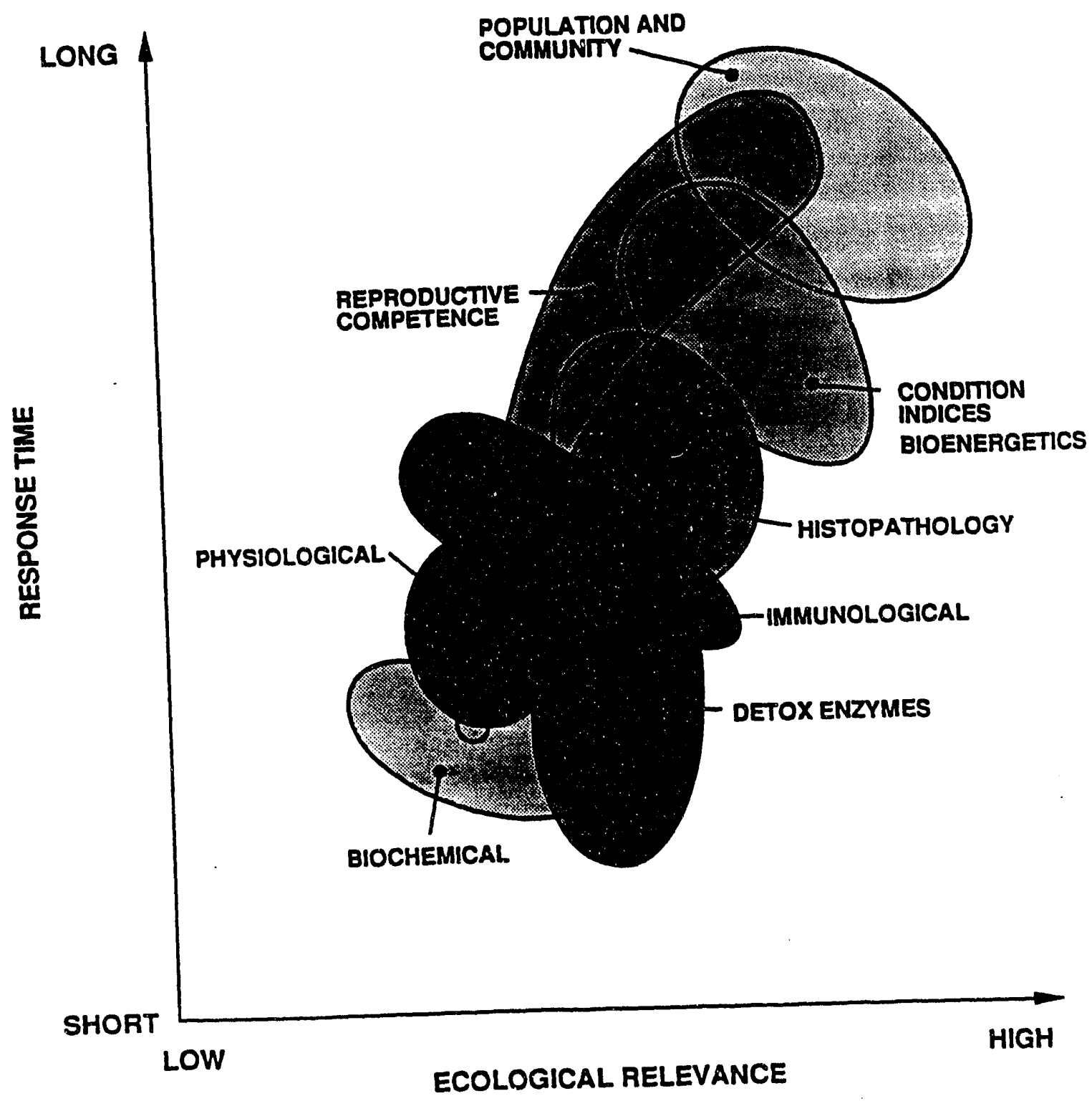

Fig. 4. The continuum, along gradients of response time and ccological relevance, of biological responses of fish to environmental stress. 


\section{Indicators of metabolic dysfunction}

Various types of biochemical assays of the blood may be used to indicate metabolic dysfunction in critical organs such as the liver, kidney, and gills. Circulating concentrations of chemicals associated with the General Adaptation Syndrome of Selye (Selye 1950) are a function of their secretion into and clearance from the blood. Indicators of cell/tissue/ organ dysfunction represent a wide variety of assays, including serum enzymes such as lysosomes and transaminases, electrolyte bomeostasis such as $\mathrm{Na}^{++}$and $\mathrm{K}^{+}$, carbohydrate and lipid metabolism (glucose and triglycerides), endocrine related hormones (corticosteriods, catecholamines), and reproductive hormones (estradiol, testosterone). Excluding reproductive hormones, which will be addressed in the subtask on reproductive effects, a variety of organ dysfunction indicators will be measured in the blood including

1. serum albumin, an important component of both osmotic regulation and the binding and transport of compounds such as fatty acids and hormones and a general indicator of liver dysfunction;

2. creatinine, an indicator of kidney damage or malfunction;

3. transaminase enzymes alanine amino transferase and amino aspartate transaminase, which are used as indicators of liver damage and reflect cirrhosis or obstructive jaundice; and

4. blood urea nitrogen, an indicator of gill dysfunction.

Indicators of pathology and tissue damage

Histopathological alterations are the net result of adverse biochemical and physiological ch. nges in an organism, and they essentially integrate the effects of these changes. Histopathological effects are also intermediate response-level indicators, reflecting biochemical and physiological effects but also serving as possible indicators of problems at higher levels of biological organization such as growth and reproductive competence of individual organisms (Fig. 4). These types of bioindicators have the advantage of being able to identify specific target organs, cells, and organelles as they are affected under in vivo conditions. Furthermore, histopathology is often the most informative approach to access acute and chronic effects of contaminant exposure in various tissues and organs (Hinton and Lauren 1990).

In this BMAP, emphasis will be placed on histopathological examination of the liver for several reasons. The liver is the major site of the detoxification (P450-mixed function oxidase) system, which inactivates some contaminants while activating others to their toxic forms. Also, nutrients from gut absorption are stored in liver cells and released for further catabolism by other tissue. Bile, which is synthesized within hepatocytes and released into the intestine, aids in digestion of fats. Finally, the liver synthesizes yolk protein or vitellogenin, which is destined for oocyte formation and thus has an important role in reproductive success of the organism. The specific histopathological indicators of liver disfunction to be measured include (1) parasitic infestation and lesions;

(2) hepatocellular necrosis and hyperplasia; (3) neoplastic lesions such as hepatic adenoma 
and hepatocellular carcinoma; (4) macrophage aggregate, and (5) functional liver tissue, which reflects the ability of the liver to perform the above functions.

\section{Indicators of bioenergetic function and lipid stores}

There are numerous energetic responses which organisms exhibit in response to toxicant-induced stress. Some of these responses can be directly related to the general adaptation syndrome (Selye 1950), which is based on the concept that energy is required to maintain homeostasis. Other responses are the direct result of toxicants interfering with key metabolic pathways. Acute responses, which are generally hormonally controlled, are considered to be the initial response to the stressor and often involve the increase of energy-related substrates in the plasma/hemolymph. Chronic stress can initiate compensatory physiological adjustments to the extent that changes in energy metabolism demand the majority of an organism's energy expenditure, with any increased maintenance requirement resulting in reduced growth or reproduction. Consequently, a comparative assessment of the energy status of an organism can be indicative of its overall condition. The energy status of fish sampled from Mitchell Branch, Poplar Creek, Clinch River, and the K-1007-P1 pond will be assessed by measuring various components of energy reserves and dynamics including (1) blood triglyceride and cholesterol levels, (2) visceral lipid stores, and (3) qualitative evaluation of liver lipids.

\section{Condition indices}

Various indices have been used to evaluate the condition or well-being of fish. The use of condition indices provides a method for "bridging the gap" between biochemical and physiological alterations at the cell and tissue level and resultant structural and functional changes at the organism and population level (Fig. 4). The major advantage of using condition indices over other bioindicators to detect and evaluate environmental stress is that they provide a relatively simple, cost-effective, and rapid indication of how well fish are coping with their environment. Condition indices, and particularly those that are representative of the whole organism, can be used to relate the consequences of biochemical and physiological alterations in the organism with observed changes in the individual and population. Many of these indices can serve as first level warning signs that signal departures from normal within the population and can, thus, focus further investigation.

As part of the bioindicators subtask, several condition indices will be measured which are based on the ratios among morphological and anatomical features of fish. These include (1) the traditional condition factor, which reflects the "plumpness" or general well-being of fish (LeCren 1951); (2) the liver-somatic index, which is indicative of both energy storage (Heidinger and Crawford 1977) and exposure to toxicants (Fletcher et al. 1982); (3) the visceral-somatic index, which indicates fat storage (Adams and McLean 1985); and the spleno-somatic index, which can be used to reflect disease or immune system problems (Gocde and Barton 1990). 


\section{Indicators of nutrition and feeding}

The nutritional status of organisms is important for interpreting and evaluating the nature of stress responses to contaminants. Environmental factors such as food and habitat availability can modify or modulate the responses of organisms to strers (Niimi 1990, Adams 1990a). As indicators of feeding intensity (which in a general v/ay reflects food availability), the percent of the stomach and intestine containing food and the size and the color of the gall bladder will be determined. The nutritional statu's of fish will be assessed based on the visceral-somatic index, percentage of viscera composed of neutral fats, and triglyceride and cholesterol levels in the blood.

\section{Population-level indicators}

The principal population-level indicators provide information on the growth and production potential of a species and on recruitment or reproductive success. Growth is an ultimate expression of fish health or condition because it integrates all the biotic and abiotic variables acting on an organism and reflects secondary impacts of chronic stress (Larkin 1978, Adams and McLean 1985). The primary population-level indicators of fish health that will be measured in sunfish collected from lower Mitchell Branch will be growth (weight and length at age) and size frequency distributions among fish populations at the various sites. No population-level indicators will be taken for fish collected from the Clinch River and Poplar Creek because of the problems associated with quantifying the population dynamics of fish in larger aquatic systems such as rivers and reservoirs.

\subsubsection{Sampling Sites and Species}

In addition to the lower Mitchell Branch site (MIK 0.12), bioindicator sampling will be conducted at selected sites in the lower sections of the Clinch River, lower Poplar Creek, and the K-1007-P1 pond (Figs. 1, 2, 3, and Table 1). All sampling and analysis protocols, including site locations, species to be sampled, and sampling frequency, will be conducted according to the CRRI Phase 2 Sampling and Analysis Plan (R. B. Cook et al., unpublished data). Sample sites on Poplar Creek include (1) PCK 18.2 or 10.7 (depending on accessibility by boat), upstream of the confluence of EFPC and Poplar Creek; (2) PCK 8.2, below the mouth of EFPC; (3) PCK 6.9, just downstream of the mouth of Mitchell Branch; and (4) PCK 1.6 on lower Poplar Creek, downstream of the K-1007-P1 pond outfall. Principal sampling sites in the Clinch River include the Jones Island area (CRK 32.7), the Brashear Island area (CRK 15.0), and the lower Clinch River before its confluence with the Tennessee River (CRK 0.5). At each of the Poplar Creek and Clinch River sites, both largemouth bass and bluegill will be collected for bioindicator analysis. For each species, the target number of individuals to be collected at each site will be $10-20$, but this number may vary among sites depending upon availability. Reference sites for Mitchell Branch will be Hinds Creek and Paint Rock Creek, and the reference site for Poplar Creek, the Clinch River and the K-1007-P1 pond will be Norris Reservoir.

In conjunction with the bioaccumulation task, fish from the K-1007B-P1 pond will be collected for bioindicator analysis. Previous studies (Ashwood et al. 1986) have identified elevated levels of heavy metals and PCBs in the sediment of the K-1007-P1 pond. 
Depending upon availability, both sunfish (bluegill) and largemouth bass will be sampled from the pond for bioindicator analysis.

\subsubsection{Sampling Frequency}

The results of previous bioindicator studies in a variety of aquatic systems (Loar et al. 1992a, 1992b; S. M. Adans, unpublished data; Adams et al. 1992a, 1992b; J. M. Loar, unpublished data, 1989, 1990, 1991, 1992; Adams and Greeley 1991) have demonstrated that, for most bioindicators, annual sampling is adequate to evaluate the effects of water quality and other environmental variables on fish health. Indeed many bioindicators, such as histopathological parameters, population-level indices, and reproductive responses, are integrative in nature, reflecting the effect of environmental variables over long time periods (Adams 1990b). As was the case under the original sampling plan, bioindicator studies in the new BMAP will continue annually in lower Mitchell Branch.

In Poplar Creek and the Clinch River, sampling will be conducted according to the CRRI Phase 2 Sampling and Analysis Plan (S. M. Adams, unpublished data). It is anticipated that sites PCK 1.6, CRK 32.7, and CRK 0.5 will be sampled in 1993 and PCK 18.2, PCK 8.2, PCK 6.9, and CRK 15.0 will be sampled in 1994. Following the 1993 and 1994 monitoring, results will be evaluated to determine whether studies in Poplar Creek and the Clinch River will continue to be conducted after 1994. As currently planned, sampling in the K-1007-P1 pond will be conducted only once to determine whether the health of fish populations is being compromised by the contaminated sediments in the pond. If adverse health effects are identified, then subsequent studies may be warranted.

\subsubsection{Reproductive Effects (Subtask 3b)}

Reproduction, the success of which is critical to the establishment and continued maintenance of viable fish populations, is widely considered to be one of the most important physiological functions affected by chronic contaminant-related stress (Birge et al. 1985). Certain phases within the reproductive processes of fish, including egg production (Suter et al. 1987) and embryonic development (J. M. Loar, unpublished data), are among the life stages that are most sensitive to environmental toxicants. For these reasons, the potential for fish reproduction to be affected by K-25 Site operations will be examined in a distinct subtask of the fish health task.

Fish reproduction involves a very complex series of processes, from gamete production, spawning, and fertilization to embryonic development and larval survival. This assessment will examine the reproductive health of fish in lower Mitchell Branch (Fig. 2), Poplar Creek, the Clinch River, and the K-1007-P1 pond (Fig. 1). Reproductive health will be evaluated by examining plasma reproductive steroid levels, gamete quantity and quality, and embryonic and early larval development (medaka embryo-larval test). Because most of the fish sampled for this task will also be used for contaminant analyses (Subtask 2a) and bioindicator assessment of fish health (Subtask 3a), reproductive health will be correlated with the levels of contaminants in fish and relevant bioindicators. 
An additional goal of this subtask is to examine the potential for fish embryonic and larval development to be adversely affected by discharges from the K-25 Site. This goal will be addressed by exposing fish embryos from laboratory stocks to water samples from Mitchell Branch, Poplar Creek, the Clinch River, and the K-1007-P1 pond during embryonic and early larval development and examining subsequent developmental responses.

Existing BMAPs include assessments of the reproductive competence of fish in EFPC and White Oak Creek near ORNL. In addition, a reproductive effects task is included in the Phase II Sampling and Analysis Plan for the CRRI (R. B. Cook et al., unpublished data). The reproductive effects subtask of the K-25 Site BMAP compliments and extends the studies already underway for these other programs.

\subsubsection{Sites and Species}

Sampling sites for the field assessment of fish reproductive hea!th will be the same as those used in the bioindicator subtask (Table 4). Medaka embryo-larval cests will be conducted on water samples from upper Mitchell Bran' I (MIK 1.43, Fig. 2), lower Mitchell Branch (MIK 0.12), various sites in Poplar Creek (YCK 18.2, PCK 8.2, PCK 6.9, PCK 4.7, PCK 1.6; Fig. 1), the Clinch River (CRK 15.9), and assorted reference sites included in the CRRI (M. S. Greeley, unpublished data). Additional sites aiong Mitchell Branch will be added if the results of preliminary embryo-larval tests suggest that such additions are warranted.

Largemouth bass and bluegill sunfish are important sport fishes in Poplar Creek and the Clinch River and are the target species to be exainined in the field portion of the reproductive effects assessment task of the CRRI. Therefore, these two species will constitute the primary fish species to be examined in Poplar Creek and the Clinch Fiver for this subtask of the K-25 Site BMAP. The redbreast sunfish is the primary sport fish found in Mitchell Branch and will be the target fish species in that stream.

The Japanese medaka (Oryzias latipes), a small fish native to Southeastern Asia, will be the fish species used in the embryo-larval testing portion of this subtask. Medaka are an increasingly popular aquatic species for both carcinogenicity and toxicity testing of chemicals. The species has several advantages for developmental toxicity testing, including (1) ease of maintenance in the laboratory, (2) reliability of obtaining eggs for testing purposes, (3) a long embryonic period with a resulting increase in sensitivity to many environmental contaminants, and (4) embryo clarity which facilitates observation of developmental abnormalities prior to hatch. Medaka are currently used in the BMAP's for EFPC and White Oak Creek, and in the CRRI.

\subsubsection{Reproductive Response Parameters}

Reproductive processes in fish are internally regulated by a complex system of hormonal mechanisms. Previous BMA.P studies have suggested that circulating levels of reproductive hormones can be useful criteria for assessing the reproductive competence of fish in a biological monitoring program (J. M. Loar, unpublished data). Plasma levels of estradiol and testosterone in female fish and 11-ketotestosterone and testosterone in males 
will be measured by radioimmunoassay, provided that sufficient plasma is available after the various plasma assays associated with the bioindicator subtask are completed.

Endocrine signals, which provide internal regulation for reproductive processes, are mediated by hormone receptors located in target cells. One of the principal targets for the action of estradiol in fish is the liver hepatocytes, which produce vitellogenin, the precursor for most of the yolk proteins that eventually nourish the developing embryos and yolk-sac larvae. Various compounds, including PCBs, have been shown to have antiestrogenic or estrogenic effects and act primarily at the estrogen receptor to compete for estrogen binding sites. Cytosolic, nuclear, and total estrogen binding capacity in hepatocytc, will be measured in both male and female largemouth bass from Poplar Creek and the Clinch River. Because the supply of liver tissue is limited in bluegill sunfish and redbreast sunfish, estrogen receptor binding will not be quantified in these species.

Gonadal condition will be assessed by calculating the gonadal-somatic index and by visual examination of gonadal appearance (color and shape and, in females, gross appearance of the oocytes). In addition, estimates of oocyte abundance and developmental stages will be made for females of each species. Particular emphasis will be placed on determining fecundity through enumeration of oocytes in the developing clutches, quantifying oocyte atresia and reabsorption, and obtaining a value for total vitellogenic oocytes (an indirect measure of the bioenergetic effort expended during the reproductive process). One testis from each male will be examined histologically for the occurrence of obvious developmental abnormalities in the spermatogenic stages.

Assessment criteria for the medaka embryo-larval test will include hatching success, time-tu-hatch, the incidence of developmental abnormalities during both embryonic and early larval 2 velopment, and the survivorship of embryos and yolk-sac larva.

\subsubsection{Sampling Period and Frequency}

The breeding seasons of largemouth bass, bluegill sunfish, and redbreast sunfish are all characterized by a relatively synchronous onset of spawning activity in the spring. Largemouth bass begin spawning in Poplar Creek and the Clinch River in late March or early April. Both redbreast sunfish and bluegill sunfish begin spawning in early to midMay. Initial spawning periods for all three species typically last about 1-2 weeks. Following the first major spawning episode, the reproductive activities of individual fish become more asynchronous, although most adults apparently participate in at least one additional series of spawns during the breeding season. Because of very high within-site variability in the reproductive condition of these fish later in the breeding season, amongsite comparisons of reproductive competence will be made using fish collected only during the first spawning episode.

Largemouth bass and bluegill will be collected annually from Poplar Creek, the Clinch River, and the K-1007-P1 pond in early to late spring. Redbreast sunfish will be collected from lower Mitchell Branch ( $\sim$ MIK 0.12) once annually in late spring (Table 4). Medaka embryo-larval tests will be conducted quarterly in conjunction with the ambient toxicity monitoring tests of water from Mitchell Branch, Poplar Creek, the Clinch River, 
and selected reference sites. Sites and frequency for the medaka embryo-larval tests will be reevaluated following the completion of one annual series of quarterly tests.

\subsubsection{Data Handling and Analysis}

Data associated with the field assessment of fish reproductive health will be collected, processed, and analyzed according to the biological indicators of contaminant-related stress (Adams and Greeley 1992). Medaka embryo-larval tests will be conducted according to procedure 2162 in CRERP (1992). Appropriate multivariate, canonical discriminant analysis, and nonparametric statistical techniques will be used to determine whether (1) significant differences exist between the reproductive condition of fish at reference sites and sites potentially affected by K-25 Site operations, (2) differences in reproductive condition between sites are related to either contaminant burdens in fish or downstream proximity to the K-25 Site, and (3) water collected downstream of the K-25 Site can adversely affect fish embryonic and prolarval development as compared with either laboratory controls or water from upstream reference sites. Data from this reproductive effects assessment subtask will also be correlated with results from the biological indicators subtask (Subtask 3a) and with the results of ambient toxicity monitoring (Task 1).

\section{INSTREAM MONTTORING (TASK 4)}

\subsubsection{Introduction}

One BMAP task (Task 4) that was initiated following the issuance of a modified NPDES permit for the K-25 Site in September 1986 was that of Instream Monitoring. This task included benthic macroinvertebrate (Subtask 4a) and fish (Subtask 4b) community studies in Mitchell Branch (Loar et al. 1992b). The major objectives of these two subtasks were to (1) characterize the spatial and temporal patterns of these communities in Mitchell Branch, and (2) document the effects of new pollution abatement facilities on community structure and function.

Results of the benthic macroinvertebrate community studies showed that, relative to the upstream reference site (MIK 1.43), that portion of Mitchell Branch immediately adjacent to the main K-25 Site was significantly impacted (J. G. Smith, unpublished data). Greatest impact was evident just downstream of SD 170 at MIK 0.71, where several major groups of invertebrates were conspicuously absent (e.g., Ephemeroptera, Plecoptera, and Trichoptera). Significant improvement was evident at the two sites located downstream of MIK 0.71 (sites MIK 0.54 and MIK 0.45 below SD 180 and SD 190 respectively). However, relative to MIK 1.43 , the stream was still significantly impacted at these two sites, where major taxonomic groups were absent as well. Results of the fish community studies in Mitchell Branch also indicated substantial adverse impact, but recovery was recently evident. Fish populations declined and/or disappeared during the period 1986-90 (J. G. Smith; J. G. Smith et al., unpublished data). During 1991 fish reappeared at all sites below SD 170 with densities equalling or surpassing levels observed in 1986 (M. G. Ryon, Environmental Sciences Division, ORNL, unpublished data). The timing of the recovery corresponded with the dechlorination of effluents in May 1991, which probably accounts for the rapid increase in fish density. This recovery included MIK 0.71 , which in previous surveys had no resident fish community. However, the recovery is iimited to 
increases in density, while species richness remains low, indicating that the fish community of Mitchell Branch is still impacted.

Instream monitoring will continue as a BMAP task through the renewed NPDES permit that was issued for the K-25 Site on October 1, 1992. This task will again consist of benthic macroinvertebrate (Subtask 4a) and fish (Subtask 4b) community studies. Although the general plan of each subtask is similar to the ones implemented during the earlier permit (Loar et al. 1992b), several modifications are proposed. The revised task, which is based on results obtained since 1986, will still have the capability to document the effects of new pollution abatement facilities or detect major perturbations should they occur. However, it will place greater emphasis on detecting temporal changes at each monitoring site in order to assess the response of biota in Mitchell Branch to abatement activities. Differences among sites will continue to be evaluated in order to identify areas and/or sources of major perturbations and to assist in documenting changes associated with pollution abatement activities.

\subsubsection{Benthic Macroinvertebrates (Subtask 4a)}

The benthic macroinvertebrate monitoring task will involve the collection of either quantitative or semiquantitative samples from several stream sites on or near the K-25 Site. The type of sample collected from a given site will depend upon the designated purpose of the site. For example, quantitative samples will be collected from those sites that require statistically definitive results (i.e., compliance based sampling), whereas semiquantitative samples will be used as a screening tool to provide a preliminary evaluation of those sites that may be impacted by past or current operations at the K-25 Site (i.e., exploratory sampling).

Quantitative benthic macroinvertebrate samples will be collected from four sites on Mitchell Branch that have been sampled since the K-25 Site BMAP was initiated in 1986 (Loar et al. 1992b), including MIK 0.45, MIK 0.71, MIK 0.78, and MIK 1.43 (Fig. 2). Although MIK 1.43 will continue to serve as the primary reference site (Fig. 2), data obtained from reference sites used in other ORR monitoring programs (Loar et al. 1991; Southworth et al. 1992) will be used, as appropriate.

The use of only four sites on Mitchell Branch represents a modification in the original BMAP which utilized six sites (Loar et al. 1992b). The two sites that will be dropped are MIK 0.54 and MIK 0.86 . Because of the close proximity of MIK 0.86 to MIK 0.78 and of MIK 0.54 to MIK 0.45 , as well as the relative similarities of the benthic communities at these site-pairs (J. G. Smith, unpublished data), any major changes in the invertebrate community should be detectable at the retained sites. Dropping MIK 0.54 is further justified because the effluent from SD 180, which is just upstream of MIK 0.54 , was toxic less frequently than the effluent from SD 190, which is just upstream of MIK 0.45 (Table 2). With continued toxicity testing of effluents from SD 180 and SD 190 (Sect. 2.1), the retention of a benthic macroinvertebrate monitoring site at MIK 0.45 , which is downstream of both storm drains, will allow the detection of major changes in Mitchell Branch that may be associated with discharges from either storm drain. Likewise, dropping MIK 0.86 is supported by the fact that there are no major effluent discharges upstream of MIK 0.78; thus, the existence of a single site between MIK 1.43 and SD 170 
should allow the detection of any major changes should they occur in this portion of the stream.

Semiquantitative samples will be collected in spring 1993 from two streams on the K-25 Site. These streams include an east tributary to the K-1007-P5 Pond near the southern boundary of the K-25 Site (Fig. 1) and the unnamed East Tributary of Mitchell Branch that approximately parallels the entrance road to Portal 6 (Fig. 2). In addition, a semiquantitative sample will be collected concurrently from the reference site on Mitchell Branch (MIK 1.43) to use as a basis for comparison with these tributary sites to determine whether either tributary has been, or is being, impacted by activities at the K-25 Site. A preliminary site visit will be made to determine the number of sites to be sampled in each tributary prior to sample collection; habitat in each stream will be evaluated to determine suitability for the collection of samples and to look for areas that show evidence of possible impact (e.g., silt and/or excessive growths of algae, which would be indicative of unnatural inputs of nutrients). The results of the semiquantitative samples will be evaluated to determine whether the benthic communities of the streams are impacted. If impact is evident at any site, the decision on the need for and extent of additional sampling will be made together by appropriate representatives from the K-25 Site, the ORNL Biomonitoring Group, and the TDEC.

Finally, benthic macroinvertebrate community studies will not be conducted in other bodies of water (i.e., Poplar Creek and Clinch River) that receive discharges from K-25 Site operations because dilution is substantial (i.e., each discharge contributes less than $1 \%$ of the flow in the receiving water). Any ecological effects of these effluents, if they exist, are probably very localized and would not be detectable in these relatively large bodies of water.

\subsubsection{Quantitative Sample Collection and Analysis}

Three randomly selected quantitative benthic macroinvertebrate samples will be collected quarterly from designated riffle areas at each site in Mitchell Branch with a Surber sampler $\left(0.09 \mathrm{~m}^{2}\right.$ or $\left.1 \mathrm{ft}^{2}\right)$ fitted with a $363-\mu \mathrm{m}$-mesh collection net. The samples will be preserved in $80 \%$ ethanol, which will be replaced with fresh $80 \%$ ethanol within 1 week after collection of the samples. Additional details of the field and associated QA procedures that will be followed in the collection and maintenance of quantitative samples are given in Smith (1992).

Although samples from Mitchell Branch will be collected on a quarterly basis, only samples collected in the spring and fall will be processed, while samples collected in the winter and summer will be retained in storage to provide further resolution of the data only if needed. Differences among sites, particularly those between the reference site (MIK 1.43) and the downstream sites, are substantial (J. G. Smith; J. G. Smith et al., unpublished data). Detection of differences as great as these does not require a data set as large as the one that would be provided by processing all four quarter's samples. The factor(s) triggering the need for processing the stored samples (i.e., summer/winter) will include but not necessarily be limited to strongly significant (1) spatial and/or (2) temporal differences that were not observed previously. In determining what constitutes a strongly significant difference, greater consideration will be given to the results of the statistical analyses on the most sensitive parameters, such as total taxonomic richness and the 
combined richness of the Ephemeroptera, Plecoptera, and Trichoptera (EPT). Additionally, the magnitude of change(s) between sites or years will also be considered. The number of stored samples to be processed will be determined by the ability to confirm or refute the results that triggered the need for processing these samples. In most cases, the number of samples needed would include those required to provide at least two consecutive years of confirmation or refutation. The only samples to be processed will be those needed to help verify the accuracy of the observed changes (e.g., changes at the reference site versus changes at an affected site).

In the laboratory, processing of the samples will include the separation of benthic organisms from the sample debris (e.g., gravel and detritus) in white enamel pans at a magnification of $2 x$. The organis $n s$ will be identified to the lowest practical taxonomic level and enumerated; however, identification of oligochaetes (aquatic earthworms) will be limited to class, and chironomids will be identified to subfamily and tribe only. Biomass has been found to be time consuming to obtain (J. G. Smith, unpublished data), and relative to parameters such as total richness and EPT richness, the reliability of biomass data for identifying impacts or other changes in streams is erratic (e.g., J. G. Smith, unpublished data; Southworth et al. 1992); therefore, biomass will not be determined. A detailed description of the laboratory and associated QA procedures that will be followed while processing each sample is given in Wojtowicz and Smith (1992).

Management and analyses of quantitative data will be accomplished on computer with the Statistical Analysis System (SAS 1985a, 1985b). Analyses will include, but not necessarily be limited to, parametric statistical procedures (e.g., analysis of variance) to help identify significant betwecn-year and between-site changes in the benthic community; various parameters such as density, total taxonomic richness, and EPT richness will be analyzed. Prior to statistical analysis with parametric procedures, appropriate transformations (Elliot 1977) will be applied as necessary. Where beneficial or necessary, data on water quality or from other tasks or BMAPs (e.g., J. M. Loar, unpublished data, 1992; Southworth et al. 1992) will be used to aid in the interpretation of results.

\subsubsection{Semiquantitative Sample Collection and Analysis}

Although a qualitative procedure will be used to collect benthic macroinvertebrates from two small tributary streams, each sample will be processed in a way that will allow the resulting data to be analyzed semiquantitatively; therefore, the samples collected using the following procedures will be referred to as semiquantitative. One semiquantitative sample will be collected from each site with an aquatic dip net (mesh of $500 \mu \mathrm{m}$ ) by disturbing all identifiable habitat types (e.g., riffles, pools, leaf packs, undercut banks, moss, aquatic plants, root mats, etc.) by foot and/or hand and then holding the net downstream of, or sweeping the net through, the suspended materials and organisms. Depending upon the size of the stream and the diversity of habitat, a reach of approximately $50 \mathrm{~m}$ will be sampled at each site over a 10- to $15-\mathrm{min}$ period. After a sample has been collected, it will be preprocessed in the field by placing it into a large bucket partially filled with water, vigorously swirling the sample in the water to suspend the lighter debris and organisms, and then pouring the suspended materials and water through a fine-meshed net (mesh of $363 \mu \mathrm{m}$ ), being careful not to allow large pieces of debris and rocks to enter the net. These latter two steps will then be repeated three or more times until the entire contents of the dipnet have been processed. The material in 
the fine-meshed net will be transferred into a prelabeled, plastic-coated, glass jar and preserved in approximately $80 \%$ ethanol. The coarser material remaining in the bucket will be placed into an $8 \times 10$-in. white, plastic tray and visually scanned for additional organisms, particularly heavier organisms such as mollusks (snails and clams) and insects that use rocks and other debris for construction of cases; any additional organisms removed will also be placed into the sample container. Each sample will then be returned to the laboratory for final processing. The ethanol in all samples not processed in the laboratory within one week after collection will be replaced with fresh $80 \%$ ethanol.

As semiquantitative samples are processed in the laboratory, each sample will initially be washed and retained in a \#60 sieve (250- $\mu \mathrm{m}$ mesh) using the same procedures as those followed for washing ethanol from quantitative benthos samples (Wojtowicz and Smith 1992). Each sample will be processed in two stages: semiquantitative and qualitative. For the first stage (i.e., semiquantitative stage), a small amount of sample (i.e., $\sim 1$ teaspoon) will be randomly removed from the sieve and placed into an $8 \times 10$-in. white, plastic tray containing water, and all organisms will be removed from the debris under $2 \times$ magnification. After this process is repeated nine additional times, the organisms from these first ten trays will be identified to the lowest practical taxon and the total number of individuals of each taxon counted. The remainder of the sample is included in the second processing stage (i.e., qualitative stage). This stage will entail placing small portions of the sample into a white, plastic tray and then removing only specimens of those taxa not observed during the first processing stage; this process will be repeated until the entire sample has been sorted. The organisms removed during the second stage of processing will be identified only. The organisms and data from the qualitative and semiquantitative portions of each sample will be maintained separately.

Management and analyses of semiquantitative and qualitative data will be done on computer with the Statistical Analysis System (SAS 1985b). Analyses of semiquantitative data will include, but not necessarily be limited to, simple, nonstatistical, site comparisons of parameters such as relative abundances of major taxa, total taxonomic richness, and EPT richness. Data from the qualitative portion of each sample will be used to supplement data on taxonomic richness and composition obtained from the semiquantitative portion of the sample.

\subsubsection{Fishes (Subtask 4b)}

The fish community will be sampled quantitatively at two sites in Mitchell Branch (Fig. 2) and at one site in a nearby reference stream. The sites in Mitchell Branch (MIK 0.45 and MIK 0.71 ) are two of the original four sites that have been sampled routinely since 1986 . MIK 0.45 is the most downstream site and is immediately below SD 190. The next upstream site, MIK 0.54, was included in the initial BMAP to assess the impacts of SD 180 effluent separately from SD 190 effluent. Fish monitoring data have indicated no significant differences between MIK 0.54 and MIK 0.45 ; both sites had similar temporal changes in fish density, biomass, and richness (M. G. Ryon, unpublished data). MIK 0.71 is located downstream of SD 170 and will continue to be sampled. Historically, MIK 0.71 has reflected the most severe impact from SD 170 effluent and has effectively reflected, as well, the recovery of the fish community following dechlorination of SD 170 in May 1991. The most upstream fish sampling site, MIK 0.78, will no longer be sampled. The length of the site is restricted by culverts, and SD 170 effluent is 
discharged midway within the site. Consequently, the reach at MIK 0.78 has always included areas subject to different effluents and flow regimes. These differences created a section of stream above SD 170 which acts as a refuge for fish from toxic effluents and has thus resulted in potentially misleading data. In the current plan, fish sampling at MIK 0.71 will be used to monitor the historically most toxic effluent, and sampling at MIK 0.45 will be used to monitor conditions downstream of all major effluents and perturbations.

The original reference site, MIK 1.43, was dropped from the sampling program in fall 1988 because the shallow water did not provide fish habitat similar to the downstream sites; the absence of similar habitat made fish community comparisons invalid. The reference site on upper Mitchell Branch was replaced by Grassy Creek (GCK 2.4). However, construction activities and substantial clearing of land near the stream have resulted in a site that was no longer minimally disturbed, as required of all BMAP reference sites. Therefore, a new reference site will be chosen from comparable streams (e.g., Mill Branch or Gum Hollow Branch, tributaries of EFPC) on ORR.

Qualitative sampling will be conducted in other reaches of Mitchell Branch, as necessary. Some of this sampling will involve coordination with the bioaccumulation task (see Sect. 2.2). The goals of the qualitative sampling are (1) to characterize immigration of fish from Poplar Creek into Mitchell Branch and (2) to detect gross changes in the fish community composition outside the quantitative sampling reaches.

Additional fish community sampling will not be conducted in Poplar Creek or the Clinch River to assess impacts of the K-25 Site effluents. Previous studies have adequately described the fish communities in these areas, and no significant effects of plant operations on these communities was observed (Loar et al. 1981). Because K-25 Site discharges constitute less than $1 \%$ of the total flow of the receiving streams, any impacts of K-25 Site discharges on these streams would be minimal and probably could not be distinguished from the associated impacts of impoundment, agricultural runoff, and domestic sewage disposal.

\section{Methods}

Quantitative sampling of the fish community will be conducted at the three sites in the spring and fall of each year. One Smith-Root Model 15A backpack electrofisher will be used and all stunned fish will be collected. Block-nets will be used at the upper and lower ends of the $25-$ to $50-\mathrm{m}$ reaches to isolate the populations during sampling. Fish that are collected will be anesthetized with MS-222 (tricaine methanesulfonate), identified, measured to the nearest $0.1 \mathrm{~cm}$ (total length), weighed to the nearest $0.1 \mathrm{~g}$, and returned to the stream. Population estimates will be based on the removal method, with three consecutive passes at each site. Water quality data will be measured with a Horiba water sampler and field sampling conditions will be recorded for each samp's. Further details on sampling methods are provided in the fish community quality assurance plans (Ryon 1992).

Qualitative sampling will be limited to procedures adequate for compiling a species list for each section of the stream. This sampling involves electrofishing a known area or for a limited period of time. All stunned specimens are collected and identified to species in the field before being released. Any specimens that are unusual or difficult to identify will be preserved in formalin and returned to the laboratory for processing. 


\section{Quantitative data analysis}

Quantitative data analysis will include determinations of species richness, density, biomass, length-frequency, species sensitivity, and annual production. Species population estimates are calculated using the three-pass removal method of Carle and Strub (1978). Biomass is estimated by multiplying the population estimate by the mean weight per individual. Annual production is estimated at each site using a size-frequency method (Garman and Waters 1983). Length-frequency data are compiled using 1- or 2-cm size classes in order to evaluate the population age structure. Evaluation of species sensitivity to perturbations will be based on assessments used in the Index of Biotic Integrity (Karr et al. 1986). Total numbers, biomass, and production are divided by the surface area (in square meters) of the sampling site to calculate density, biomass, and annual production per unit area. For each sampling date, surface area is estimated by multiplying the length of sampling reach by the mean width; mean width is based on stream width measurements taken at 5-m intervals. The procedures used for calculating density, biomass, lengthfrequency, and production are given in more detail in Railsback et al. (1989). 


\section{ABATEMENT PROGRAM}

The purpose of the K-25 Site BMAP is twofold. First, it has been developed to help understand the impact that the K-25 Site has on the aquatic ecosystem in the vicinity of the site. Secondly, it will serve as a resource in the development of plans to reduce or eliminate any adverse impacts from the site and document the recovery of the aquatic ecosystem after remedial actions have taken place. Historically the BMAP efforts have focused on the impact of effluents discharged to Mitchell Branch. Results of BMAP (J. G. Smith et al., unpublished data) showed that effluents from the K-25 Site were toxic to aquatic biota. Consequently, the K-25 Site eliminated process water discharges and implemented dechlorination at the major storm drains. Under the terms of the renewed NPDES permit, these efforts will be expanded to encompass other waters within and near the K-25 Site. In order to best utilize resources in these efforts, it is necessary to (1) develop a clear understanding of what the adverse impacts of the K-25 Site are, (2) determine what parameters are involved, (3) isolate the sources, and (4) plan and implement remediation efforts.

Several problem areas have been identified in the previous BMAP (J. G. Smith et al., unpublished data), the associated Mitchell Branch Toxicity Control Plan (Shoemaker 1991), and in subsequent investigations. These include the following:

1. Total residual chlorine (TRC) entering Mitchell Branch. TRC from once-through cooling water discharged to the storm drains has been identified as a major source of toxicity in Mitchell Branch. This problem was addressed through dechlorinating the storm drain discharges and rerouting or eliminating the sources of chlorinated water. As a result of these efforts, the high concentrations of TRC discharged to Mitchell Branch have been eliminated, and the dechlorination efforts will be suspended during the winter months. The BMAP will continue to monitor Mitchell Branch in this area to evaluate the effectiveness of this action.

2. Plant-wide discharge of chlorinated water to the K-25 Site storm drain system. An engineering policy was issued to require that no new connections be made between sources of chlorinated water and the storm drains. In addition, facility operators sitewide have been tasked with determining the destination of their facility drains, and procedures have been developed to control connections to the storm drain system. Corrective actions are developed for those drains that discharge chlorinated water to storm drains as they are identified. In addition, a number of storm drains are included in a compliance schedule which requires reduction of chlorine to meet water quality criteria by October 1993.

3. Treated effluent from the K-1407-E and K-1407-F ponds. Toxicity testing of effluent from these ponds conducted from 1986 to 1991 indicated that these ponds were a significant contributor to toxicity in Mitchell Branch. This problem has been solved by eliminating the discharges to Mitchell Branch and rerouting the effluent to the CNF for treatment. From this point the treated effluent is discharged to Poplar Creek. These ponds are not scheduled to discharge to Mitchell Branch in the future but will be maintained as emergency ponds for use during heavy rainfall events. All use of the ponds will cease by October 1994. 
4. Drainage from the K-1070-B classified burial ground. The seepage enters Mitchell Branch in th vicinity of Storm Drains 180 and 190 . During wet weather periods, the

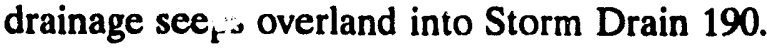

5. Runoff from the K-1417 Drum Yard. Drums of mixed wastes are stored on this concrete pad. Some of the drums are deteriorating, and rainfall possibly washes some of the material into Mitchell Branch. Runoff from the drum yard is monitored with each rainfall event. Efforts were initiated to remove and repackage the deteriorating drums in summer 1992; however, these efforts were suspended in late 1992 because of safety concerns. Because elevated contaminants were observed in the data collected on the runoff during the drum repackaging efforts, additional best management practices will continue to be developed when repackaging efforts are reinitiated.

6. Powerhouse ash pile. Power production at the coal-fired powerhouse ceased in the 1960 s. However, a large pile of ash from the boilers was left exposed to the elements. Rain leaching through the pile seeps into Poplar Creek. This seepage was known to have a very low $\mathrm{pH}$. Chemical analyses have revealed no other parameter at levels of concern. Recently steps have been taken to recontour the ash pile and neutralize the $\mathrm{pH}$ by spreading lime over the pile, with a goal of reestablishing vegetation over the pile. Toxicity will be evaluated in the portion of Poplar Creek embayment that receives this runoff as part of the revised BMAP to monitor the effectiveness of this corrective action.

7. Storm drains. The K-25 Site has a large number of storm drains. Due to the age and origin of the site, documentation of construction and modification of the drains is incomplete or nonexistent. However, a survey of the storm drain system is planned to document the existing structures. A procedure is being developed to require a permit for any operation that will result in discharges to the storm drain system. In addition, the Storm Water Pollution Prevention Plan (SWPPP) required by the NPDES permit will identify and characterize the pollutants, sources, storm water outfalls, monitoring procedures, pollution control procedures, and spill prevention and response procedures for the entire K-25 Site. Information gained from the storm drain survey and the SWPPP will be evaluated to identify areas where pollutants are being discharged to surface waters and appropriate corrective actions will be developed.

8. K-1414 garage spring. This spring discharges leachate from the $\mathrm{K}-1070-\mathrm{C} / \mathrm{D}$ burial grounds to Mitchell Branch via SD-180. It has been the subject of study and a pilot remediation effort: the Co-Metabolic Bioreactor Demonstration Project. A plan to treat the discharges using an organic air stripper and rerouting the discharge to the CNF for treatment and discharge through NPDES Outfall 011 is being developed by the Environmental Restoration organizatior. of the K-25 Site as part of an Interim Record of Decision (IROD). In the interim, until completion of the necessary treatment modifications to CNF, the water will be collected and transported to the Y-12 Groundwater Treatment Facility for disposal.

9. The potential in Mitchell Branch for sources of mercury, PCBs, and excessive silt. Elevated levels of these substances were identified in the previous BMAP. The 
extent of their contribution to Mitchell Branch toxicity will be evaluated under the SWPPP required by the NPDES permit. Best-management practices are already in place for the K-25 Site in an effort to reduce the amount of silt flowing overland from construction sites. PCBs and mercury will be investigated to determine whether the levels of these parameters in the biota of Mitchell Branch are a result of past actions.

One of the first tasks of BMAP will be to characterize the ecosystem in and around the K-25 Site. This information will then be used to target areas that require further investigation. The need for, and methods of, remediation and abatement programs will then be evaluated, and BMAP will then monitor the effectiveness of these efforts. Feedback from BMAP will then be used to help determine what modifications of the abatement program are desirable. 


\section{LITERATURE CITED}

Adams, S. M., and R. B. McLean. 1985. Estimation of largemouth bass, Micropterus salmoides Lacepede, growth using the liver-somatic index and physiological variables. J. Fish Biol. 26:111-126.

Adams, S. M., K. L. Shepard, M. S. Greeley, B. D. Jimenez, M. G. Ryon, L. R. Shugart, and J. F. McCarthy. 1989. The use of bioindicators for assessing the effects of pollutant stress on fish. Mar. Environ. Res. 28:459-464.

Adams, S. M. 1990a. Status and use of biological indicators for evaluating the effects of stress on fish. IN S. M. Adams (ed.), Biological Indicators of Stress in Fish. Amer. Fish. Soc. 8:1-8.

Adams, S. M. (ed.). 1990b. Biological Indicators of Stress in Fish. Amer. Fish. Soc. Sym. No. 8. American Fisheries Society, Bethesda, Maryland.

Adams, S. M., and M. S. Greeley. 1991. Assessment and evaluation of the ecological health of fish populations in Hartwell Reservoir exposed to PCB contamination. Final Report to the Tennessee Valley Authority, D. L. Dycus, Project Officer.

Adams, S. M., and M. S. Greeley. 1992. Biological Monitoring and Abatement Program (BMAP) Biological Indicators of Contaminant Related Stress. QA Plan. QAP-X-89ES-066. Oak Ridge National Laboratory, Oak Ridge, Tennessee.

Adams, S. M., W. D. Crumby, M. S. Greeley, and L. R. Shugart. 1992a. Responses of fish populations and communities to pulp mill effluents: a holistic assessment. Ecotoxicol. Environ. Saf. 24:347-360.

Adams, S. M., W. D. Crumby, M. S. Greeley, M. G. Ryon, and E. M. Schilling. 1992 b. Relationships between physiological and fish population responses in a contaminated stream. Environ. Toxicol. Chem. 11:1549-1557.

Ashwood, T. L., C. R. Olsen, I. L. Larsen, and P. D. Lowery. 1986. Sediment contamination in streams surrounding the Oak Ridge Gaseous Diffusion Plant. ORNL/TM-9791. Oak Ridge National Laboratory, Oak Ridge, Tennessee.

Birge, W. J., J. A. Black, and A. G. Westerman. 1985. Short-term fish and amphibian embryo-larval tests for determining the effects of toxicant stress on early life stages and estimating chronic values for single compounds and complex effluents. Environ. Toxicol. Chem. 4:807-821.

Blaylock, B. G., and M. L. Frank. 1992. Biota Sampling Plan. pp. 104-140. IN P. L. Goddard (ed.). Remedial Investigation Work Plan for the K-901 Operable Unit at the Oak Ridge K-25 Site, Oak Ridge, Tennessee, Vol. 2: Sampling and Analysis Plan. DOE/OR-1052/V2 \& D1. Environmental Restoration Program, Martin Marietta Energy Systems, Inc., Oak Ridge, Tennessee.

Blaylock, B. G., M. L. Frank, and D. K. Cox. 1992. BMAP waterfowl monitoring. QAPX-92-ES-086. Oak Ridge National Laboratory.

Cairns, J., and W. H. Van der Schalie. 1980. Biological monitoring, Part I: early warning systems. Water Res. 14:1179-1196.

Capuzzo, J. M. 1985. Biological effects of petroleum hydrocarbons on marine organisms: integration of experimental results and predictions of impacts. Mar. Environ. Res. 17:272-276.

Carle, F. L., and M. R. Strub. 1978. A new method for estimating population size from removal data. Biometrics 34:621-630. 
Chamber, J. E., and J. D. Yarbrough. 1976. Xenobiotic biotransformation systems in fishes. Comp. Biochem. Pliysiol. 55C:77-84.

CRERP (Clinch River Environmental Restoration Program). 1992. Clinch River Environmental Restoration Program Procedures and Instructions Manual. ES/ER/INT-72. Oak Ridge National Laboratory, Oak Ridge, Tennessee.

Cook, R. B., S. M. Adams, M. S. Bevelhimer, B. G. Blaylock, C. C. Brandt, C. J. Ford, M. L. Frank, M. J. Gentry, S. K. Holladay, L. A. Hook, D. A. Levine, R. C. Longman, C. W. McGinn, J. L. Skiles, G. W. Suter, and L. F. Williams. 1992. Environmental Restoration Division, Clinch River Environmental Restoration Program. Phase 1 Data Summary Report for the Clinch River Remedial Investigation: Health Risk and Ecological Risk Screening Assessment. ORNL/ER-155. Environmental Sciences Division, Clinch River Environmental Restoration Program, Energy Systems Environmental Restoration Program. Oak Ridge National Laboratory, Oak Ridge, Tennessee.

Environmental Sciences Division, Clinch River Environmental Restoration Program, Energy Systems Environmental Restoration Program.

DOE (Department of Energy). 1979. Environmental assessment of the Oak Ridge Gaseous Diffusion Plant. DOE/EX-0106. U.S. Department of Energy, Technical Information Center, Oak Ridge, Tennessee.

Elliot, J. M. 1977. Some methods for the statistical analysis of samples of benthic invertebrates. Sci. Publ. No. 25. Freshwater Biological Association, Ambleside, England.

Elwood, J. W. 1984. Mercury contamination in Poplar Creek and the Clinch River. ORNL/TM-8893. Oak Ridge National Laboratory, Oak Ridge, Tennessee.

EPA (Environmental Protection Agency). 1990. Toxic Substance Spreadsheet. U.S. Environmental Protection Agency, Region-4, Water Management Division, Atlanta, Georgia. Mimeo.

FDA (Food and Drug Administration). 1984a. Polychlorinated biphenyls (PCBs) in fish and shellfish: Reduction of tolerances; final decision. Fed. Regist. 49(100):21514-21520.

FDA (Food and Drug Administration). 1984b. Action level for methylmercury in fish. Fed. Regist. 49:45663.

Fletcher, G. L., M. J. King, J. W. Kiceniuk, and R. F. Addision. 1982. Liver hypertrophy in winter flounder following exposure to experimentally oiled sediments. Comp. Biochem. Physiol. 73C:457-462.

Garman, G. C., and T. F. Waters. 1983. Use of the size-frequency (Hynes) method to estimate annual production of a stream fish population. Can. J Fish. Aquat. Sci. 40:2030-2034.

Goede, R. W., and B. A. Barton. 1990. Organismic indices and an autopsy-based assessment as indicators of health and condition of fish. Amer. Fish Soc. Sym. 8:93-108.

Hazel, J. R., and C. L. Prosser. 1974. Molecular mechanisms of temperature compensation in poikilotherms. Physiol. Rev. 54:620-677.

Heath, A. G. 1987. Use of physiological and biochemical measures in pollution biology. pp. 221-234. IN A. G. Heath (ed.). Water pollution and fish physiology. CRC Press, Boca Raton, Florida. 
Heidinger, R. C., and S. D. Crawford. 1977. Effect of temperature and feeding rate on the liver-somatic index of the largemouth bass, Micropterus salmoides. J. Fish. Res. Bd. Can. 34:633-638.

Hinton, D. E., and D. J. Lauren. 1990. Integrative histopathological approaches to detecting effects of environmental stressors on fishes. Am. Fish. Soc. Sym. 8:51-66.

Hoffman, F. O., B. G. Blaylock, C. C. Travis, K. L. Daniels, E. L. Etnier, K. E. Cowser, and C. W. Weber. 1984. Preliminary screening of contaminants in sediments. ORNL/TM-9370. Oak Ridge National Laboratory, Oak Ridge, Tennessee.

Horowitz, R. J. 1978. Temporal variability patterns and distributional patterns of stream fishes. Ecol. Monog. 47:307-321.

Karr, J. R., K. D. Fausch, P. L. Angermeier, P. R. Yant, and I. J. Schlosser. 1986. Assessing biological integrity in running waters: A method and its rationale. Spec. Publ. 5. Illinois Natural History Survey, Champaign, Illinois.

Kasten, J. L. 1986. Resource Management Plan for the Oak Ridge Reservation, Vol. 21: Water Conservation Plan for the Oak Ridge Reservation. ORNL/ESH-1/N21. Oak Ridge National Laboratory, Oak Ridge, Tennessee.

Kornegay, F. C., D. C. West, R. A. Evans, S. T. Goodpasture, M. F. Tardiff, and A. R. Wilson. 1991. Oak Ridge Reservation Environmental Report for 1990. ES/ESH18/V1. Oak Ridge National Laboratory, Oak Ridge, Tennessee.

Kszos, L. A., A. J. Stewart, L. F. Wicker, L. E. Roberson, and T. L. Phipps. 1989. Environmental Sciences Division Toxicology Laboratory Quality Assurance Program. QAP-X-89-ES-002. Oak Ridge National Laboratory, Oak Ridge, Tennessee.

Larkin, P. A. 1978. Fisheries management: an essay for ecologists. Ann. Rev. Erol. Sys. 9:57-73.

LeCren, E. D. 1951. The length-weight relationship and seasonal cycle in gonad weight and condition in the perch (Perca fluviatillis). J. Anim. Ecol. 20:201-219.

Loar, J. M., F. A. Burkhart, G. F. Cada, J. W. Huckabee, J. T. Kitchings, K. D. Kumar, A. M. Sasson, J. A. Solomon, and J. D. Story. 1981. Ecological studies of the biotic communities in the vicinity of the Oak Ridge Gaseous Diffusion Plant. ORNL/TM-6714. Oak Ridge National Laboratory, Oak Ridge, Tennessee.

Loar, J. M. et al. 1992a. First annual report on the Biological Monitoring and Abatement Program at Oak Ridge National Laboratory. ORNL/TM-10399. Oak Ridge National Laboratory, Oak Ridge, Tennessee.

Loar, J. M. et al. 1993. Second annual report on the ORNL Biological Monitoring and Abatement Program. ORNL/TM-10804. Oak Ridge National Laboratory, Oak Ridge, Tennessee.

Loar, J. M., S. M. Adams, L. J. Allison, B. G. Blaylock, H. L. Boston, M. A. Huston, B. L. Kimmel, C. R. Olsen, J. G. Smith, G. R. Southworth, A. J. Stewart, and B. T. Walton. 1991. Oak Ridge National Laboratory Biological Monitoring and Abatement Program for White Oak Creek watershed and the Clinch River. ORNL/TM-10370. Oak Ridge National Laboratory, Oak Ridge, Tennessee.

Loar, J. M., S. M. Adams, L. A. Kszos, M. G. Ryon, J. G. Smith, G. R. Southworth, and A. J. Stewart. 1992b. Oak Ridge Gaseous Diffusion Plant Biological Monitoring and Abatement Program for Mitchell Branch. ORNL/TM-11965. Oak Ridge National Laboratory, Oak Ridge, Tennessee. 
Loar, J. M., S. M. Adams, L. J. Allison, M. C. Black, H. L. Boston. A. J. Gatz, Jr., R. L. Hinzman, M. A. Huston, B. D. Jimenez, J. F. McCarthy, S. D. Reagan, J. G. Smith, G. R. Southworth, and A. J. Stewart. 1992c. First report on the Oak Ridge Y-12 Plant Biological Monitoring and Abatement Program for East Fork Poplar Creek. Y/TS-886. Oak Ridge Y-12 Plant, Oak Ridge, Tennessee.

Lowery, J. F., P. H. Counts, H. L. Edmiston, and F. D. Edwards. 1987. Water Resources Data for Tennessee, Water Year 1986, Report No. USGS/WRD/HD-87/225. U.S. Geological Survey, Nashville, Tennessee.

MacIntosh, D. L., G. W. Suter II, and F. O. Hoffman. 1992. Model of the PCB and mercury exposure of mink and great blue heron inhabiting the off-site environment downstream from the U.S. Department of Energy, Oak Ridge Reservation. ORNL/ER-90. Oak Ridge National Laboratory, Oak Ridge, Tennessee.

McMaster, W. M. 1967. Hydrologic data for the Oak Ridge area, Tennessee. U.S. Geological Survey-Water Supply Paper No. 1838-N. U.S. Government Printing Gffice, Washington, D.C.

NOAA (National Oceanic and Atmospheric Administration). 1990. Local climatological data: monthly summaries for 1989, Oak Ridge, Tennessee. National Climatic Data Center, Asheville, North Carolina.

NOAA (National Oceanic and Atmospheric Administration). 1991. 1990 annual summary with comparative data, Oak Ridge, Tennessee. National Climatic Data Center, Asheville, North Carolina.

Niimi, A. J. 1990. Review of biochemical methods and other indicators to assess fish health in aquatic ecosystems containing toxic substances. Great Lakes Res. 16:529-541.

Railsback, S. F., B. D. Holcomb, and M. G. Ryon. 1989. A computer program for estimating fish population sizes and annual production rates. ORNL/TM-11061. Oak Ridge National Laboratory, Oak Ridge, Tennessee.

Ryon, M. G. 1992. Biological Monitoring and Abatement Program (BMAP) Fish Community Studies Project QA Plan. QAP-X-90-ES-067. Oak Ridge National Laboratory, Oak Ridge, Tennessee.

SAS (SAS Institute, Inc.). 1985a. SAS User's Guide: Statistics, Version 5 Edition. SAS Institute, Inc., Cary, North Carolina.

SAS (SAS Institute, Inc.). 1985b. SAS User's Guide: Basics, Version 5 Edition. SAS Institute, Inc., Cary, North Carolina.

Sastry, A. N., and D. C. Miller. 1981. Application of biochemical and physiological responses to water quality monitoring. pp. 265-294. IN F. J. Vernberg,

A. Calabrease, F. Thurberg, and W. Vernberg, (eds.). Biological monitoring of marine pollutants. Academic Press, New York.

Scheib, W. J. 1987. ORGDP storm drain characterization. K/HS-128, Part 2. Oak Ridge Gaseous Diffusion Plant, Oak Ridge, Tennessee.

Selye, H. 1950. Stress and the general adaptation syndrome. British Med. J. 1:1383-1392.

Shoemaker, B. A. 1991. Toxicity Control Plan for Mitchell Branch. K/HS-354, Oak Ridge K-25 Site, Oak Ridge, Tennessee.

Smith, J. G. 1992. Biological Monitoring and Abatement Program (BMAP) Benthic Macroinvertebrate Monitoring Project Sample Collection and Storage QA Plan. QAP-X-90-ES-068. Oak Ridge National Laboratory, Oak Ridge, Tennessee. 
Southworth, G. R., J. M. Loar, M. G. Ryon, J. G. Smith, A. J. Stewart, and J. A. Burris. 1992. Ecological effects of contaminants and remedial actions in Bear Creek ORNL/TM-11977. Oak Ridge National Laboratory, Oak Ridge, Tennessee.

Southworth, G. R., and M. J. Peterson. 1992. Biological Monitoring and Abatement Program (BMAP) Bioaccumulation Monitoring Project Quality Assurance Plan. QAP-X-90-ES-065. Oak Ridge National Laboratory, Oak Ridge, Tennessee.

Stegeman, J. J., and P. J. Kloepper-Sams. 1987. Cytochrome P-450 and monooxygenase activity in aquatic animals. Environ. Health Perspect. 71:87-95.

Suter, G. W., II, A. E. Rosen, E. Linder, and D. F. Parkhurst. 1987. Hazard assessment: endpoints for responses of fish to chronic toxic exposures. Environ. Toxicol. Chem. 6: 793-809.

TDEC (Tennessee Department of Environment and Conservation). 1992. Tennessee Fishing Advisories. Division of Water Pollution Control, Nashville, Tennessee. Pamphlet.

TVA (Tennessee Valley Authority). 1985. Instream Contaminant Study, Task 4: Fish sampling and analysis. Report to U.S. Department of Energy, Oak Ridge Operations Office. Tennessee Valley Authority, Office of Natural Resources and Economic Development, Knoxville, Tennessee.

TVA (Tennessee Valley Authority). 1990. Results of fish screening studies from sites in the Tennessee and Cumberland Rivers in 1988. Tennessee Valley Authority, River Basin Operations, Water Resources, Chattanooga, Tennessee.

Travis, C. C., F. O. Hoffman, B. G. Blaylock, K. L. Daniel, C. S. Gist, and C. W. Weber. 1986. Preliminary review of TVA fish sampling and analysis report. Report of Task Group Five to Oak Ridge Task Force. Mimeo.

Weber, C. I., W. H. Peltier, T. J. Norberg-King, W. B. Horning, II, F. A. Kessler, J. R. Menkedick, T. W. Neiheisel, P. A. Lewis, D. J. Klemm, Q. H. Pickering, E. L. Robinson, J. M. Lazorchak, L. J. Wymer, and R. W. Freyberg. 1989. Short-term methods for estimating the chronic toxicity of effluents and receiving waters to freshwater organisms. 2nd ed. EPA/600/4-89/001. U.S. Environmental Protection Agency, Environmental Monitoring and Support Laboratory, Cincinnati, Ohio.

Weber, C. I. (ed.). 1991. Methods for measuring the acute toxicity of effluents and receiving waters to freshwater and marine organisms. 4th ed. EPA/600/4-90/027. U.S. Environmental Protection Agency, Environmental Monitoring and Support Laboratory, Cincinnati, Ohio.

Wojtowicz, J. A., and J. G. Smith. 1992. Biological Monitoring and Abatement Program (BMAP) Benthic Macroinvertebrate Monitoring Project Sample Processing QA Plan. QAP-X-91-ES-068. Oak Ridge National Laboratory, Oak Ridge, Tennessee. 
K/EM-24/R1

\section{INTERNAL DISTRIBUTION}

$\begin{aligned} 1 . & \text { S. M. Adams } \\ 2 . & \text { T. L. Ashwood } \\ 3 . & \text { B. G. Blaylock } \\ 4 . & \text { S. W. Christensen } \\ 5 . & \text { M. L. Coffey } \\ 6-8 . & \text { J. M. Forstrom } \\ 9 . & \text { R. E. Frounfelker } \\ 10 . & \text { C. W. Gehrs } \\ 11 . & \text { W. C. Gilbert } \\ 12 . & \text { M. S. Greeley } \\ 13 . & \text { L. E. Hall } \\ 14-23 . & \text { R. L. Hinzman } \\ 24-33 . & \text { L. A. Kszos } \\ 34-38 . & \text { J. M. Loar } \\ 39 . & \text { L. W. Long } \\ 40 . & \text { M. J. Peterson } \\ 41 . & \text { A. S. Quist }\end{aligned}$
42. R. A. Rich
43-45. J. L. Rich
46. M. G. Ryon
47-56. B. A. Shoemaker
57. J. G. Smith
58. G. R. Southworth
59. A. J. Stewart
60. S. H. Welch
61. Central Research Library
62. EMD Document Center
63-77. ESD Library
78. ER Document Management Center
79-80. Laboratory Records Dept.
81. Laboratory Records, ORNL-RC
82. K-25 Site Records Department
83. ORNL Patent Office

\section{EXTERNAL DISTRIBUTION}

84. S. Ahlstedt, Division of Water Resources, Tennessee Valley Authority, Norris, TN 37828

85. D. L. Buhaley, Environmental Operation Branch, Environmental Protection Division, SE-311, Department of Energy Oak Ridge Field Office, P.O. 2001, Oak Ridge, TN 37831

86. D. S. Day, Environmental Division, U.S. Department of Energy, Savannah River Operations Office, Box A, Aiken, SC 29802

87. P. H. Edmonds, Radian Corporation, 120 South Jefferson Circle, Oak Ridge, TN 37830

88. J. F. Franklin, Bloedel Professor of Ecosystem Analysis, College of Forest Resources, University of Washington, Anderson Hall (AR-10), Seattle, WA 98195

89. C. S. Gist, Environmental Protection Division, SE-31, Department of Energy Oak Ridge Field Office, P.O. Box 2001, Oak Ridge, TN 37831

90. R. C. Harriss, Institute for the Study of Earth, Oceans, and Space, Science and Engineering Resesarch Building, University of New Hampshire, Durham, NH 03824

91. H. W. Hibbitts, Deputy Assistant Manager, Department of Environment, Safety, and Quality, SE-30, Department of Energy Oak Ridge Field Office, P.O. Box 2001, Oak Ridge, TN 37831

92. D. R. Hopkins, U.S. Environmental Protection Agency, 345 Courtland Street, N.E., Atlanta, GA 30365

93. G. M. Hornberger, Professor, Department of Environmental Sciences, University of Virginia, Chariottesviiie, VA 22903 
94. G. Y. Jordy, Director, Office of Program Analysis, Office of Energy Research, ER-30, G-226, U.S. Department of Energy, Washington, DC 20545

95. T. Joseph, Environmental Remediation Branch, Environmental Protection Division, SE-312, Department of Energy Oak Ridge Field Office, P.O. 2001, Oak Ridge, TN 37831

96. W. A. Kocher, 1219 Riverbend Drive, Kingston, TN 37763

97. E. C. Leming, Director, DOE Oversite Division, 761 Emory Valley Road, Oak Ridge, TN 37830-7972

98. G. J. Marciante, Environmental Protection Division, SE-31, Department of Energy Oak Ridge Field Office, P.O. Box 2001, Oak Ridge, TN 37831

99. A. D. McKinney, Chief, Environmental Services, P.O. Box 40747, Ellington Agricultural Center, Nashville, TN 37204

100. C. R. Olsen, Environmental Sciences Division, Office of Health and Environmental Research, ER-74, U.S. Department of Energy, Washington, DC 20585

101. R. H. Olsen, Vice President for Research, University of Michigan, Medical Science Building II, \#5605, 1301 East Catherine Street, Ann Arbor, MI 48109-0620

102. A. Patrinos, Acting Director, Environmental Sciences Division, Office of Health and Environmental Research, ER-74, U.S. Department of Energy, Washington, DC 20585

103. S. S. Perkins, c/o Labat-Anderson, Inc., Information Resource Center, Administrative Record File, 105 Broadway, Oak Ridge, TN 37830

104. S. P. Riddle, Environmental Restoration Division, EW-91, Department of Energy Oak Ridge Field Office, P.O. Box 2001, Oak Ridge, TN 37831-8541

105. W. Schacher, Aquatic Habitat Protection Biologist, Tennessee Wildlife Resources Agency, 6032 W. Andrew Johnson Highway, Talbot, TN 37877

106. R. C. Sleeman, Environmental Restoration Division, EW-91, Department of Energy Oak Ridge Field Office, P.O. Box 2001, Oak Ridge, TN 37831-8541

107. F. J. Wobber, Environmental Sciences Division, Office of Health and Environmental Research, ER-74, U.S. Department of Energy, Washington, DC 20585

108. Office of Assistant Manager for Energy Research and Development, Department of Energy Oak Ridge Field Office, P.O. Box 2001, Oak Ridge, TN 37831-8600 

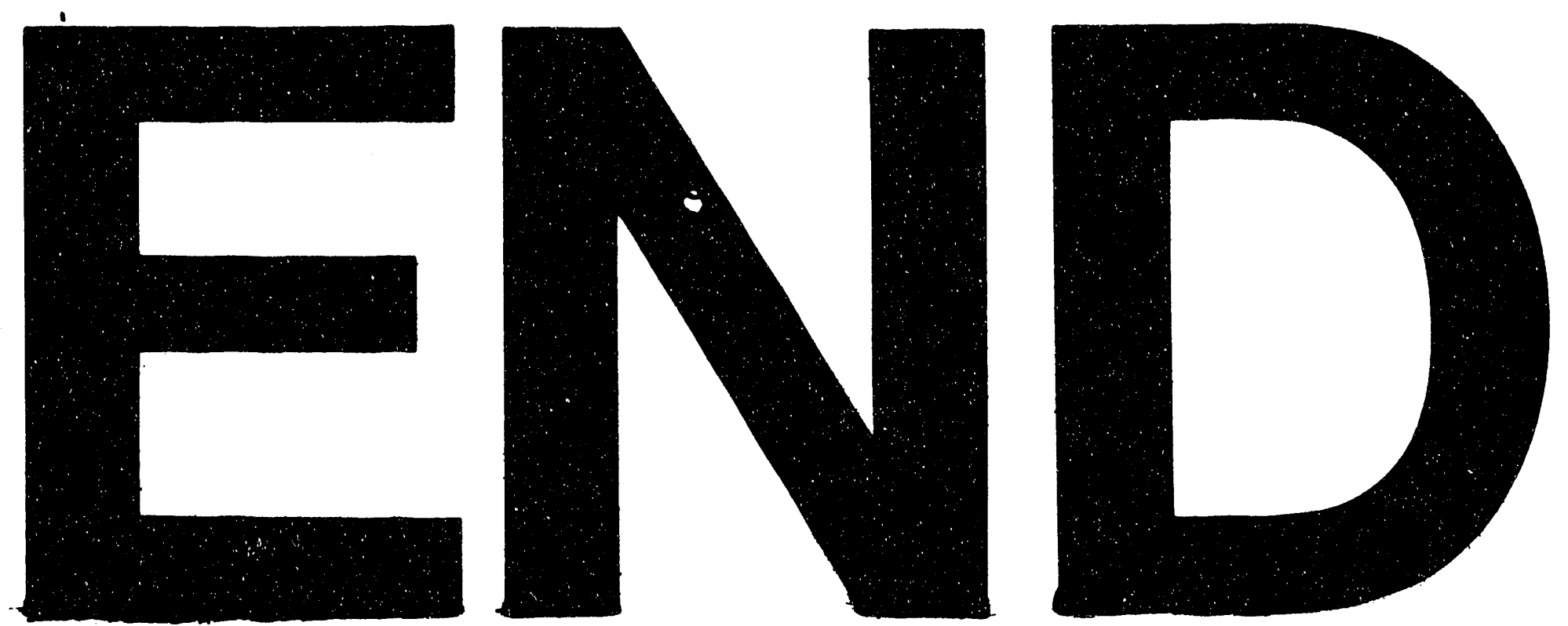

중
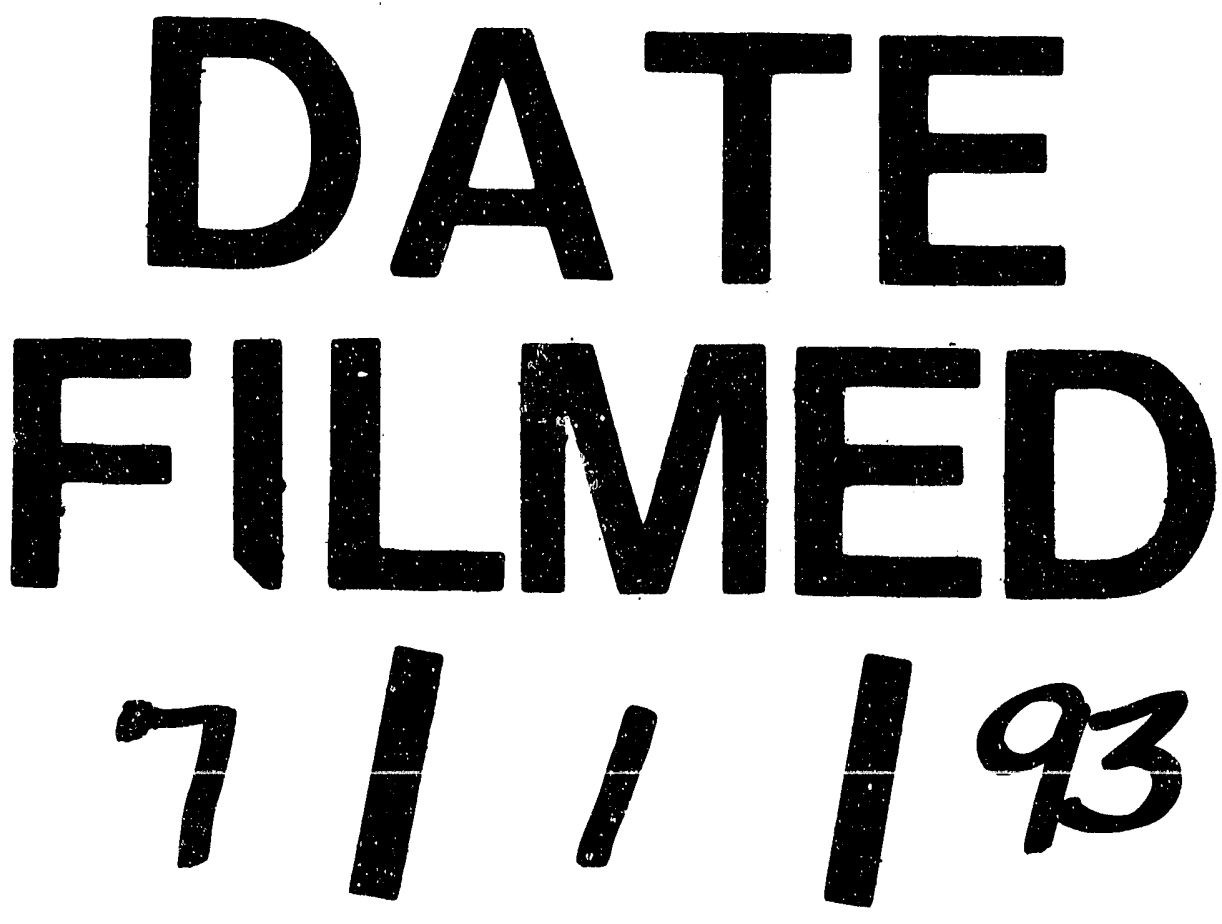
